\title{
Comment
}

\section{OUTDOOR ADVERTISING CONTROL ALONG THE INTERSTATE HIGHWAY SYSTEM}

Section 131 of the Federal-Aid Highway Act of $1958^{1}$ represents the first successful attempt to regulate roadside advertising in the United States on a national level. Applicable only to the new, controlled access Interstate and Defense Highway System, ${ }^{3}$ the act offers financial incentive to states which choose to regulate outdoor advertising in accordance with prescribed standards. The final regulatory scheme is the denouement of conflicting economic, social, and legal arguments presented to Congress by such disparate groups as roadside business associations, garden clubs, trade union councils, and nurserymen's associations. Roughly, these organizations can be divided into those with a financial interest in outdoor advertising and those with public spirited or a financial interest in beautifying the nation's highways. However, the legal rights that they usually espoused were those of the abutting landowner and of the public highway traveler. Against this background of political pressure and legal argument this comment will consider: (1) the history of attempts to impose outdoor advertising regulation on the Interstate System, (2) the provisions of section 131 and its supplementing regulations, (3) the statutory requisites for state participation in the program, (4) the scope of state power to regulate outdoor advertising, and (5) the constitutional rights of the advertiser. ${ }^{3}$

I

\section{ADVERTISING CONTROL AND THE INTERSTATE HIGHWAYS}

\section{The opening rounds}

The first legislative approach to institution of federal regulation of outdoor advertising in the history of our nation was introduced by Senator Richard Neuberger in 1955 as an amendment to the Federal-Aid Highway Bill. ${ }^{4}$ This initial scheme relied on federal purchase of advertising rights on lands adjoining the right-of-way acquired for the Interstate Highways. ${ }^{5}$ The amendment was deleted during debate on the bill largely due to the efforts of the late Senator Walter George who, raising an issue that has continued to plague the proponents

172 Stat. 904 (1958), 23 U.S.C.A. $§ I 71$ (a) (Supp. 1958). The act is reproduced in appen$\operatorname{dix}$ A following. For legislative history see U.S. Code Cong. \& AD. News, 85th Cong., 2d Sess. 729 (I958). For the English experience see, SHeldon, A Hrstory of Poster Advertising (1937).

2 The act is not applicable to the federal-aid primary or secondary systems. For a short discussion of the federal-aid highway system in general see Martin, Proposed Federal Highway Legislation in 1955, 44 Geo. L.J. 221, 224 (1956).

3 The authors would like to express appreciation to the following persons, who, annong others, were particularly kind and helpful in providing information for our use: Mr. Hans Linde, Legislative Assistant to Senator Neuberger, Mr. Ross D. Netherton, Associate Dírector Highway and Legislative Department of the American Automobile Association, and Mr. Francis Tappann, Legislative Assistant to Senator Kuchel. The authors, of course, are fully responsible for all statements and opinions in this comment.

4 Hearings on S. 963, S. 3041, S. 3218 Before a Subcommittee of the Senate Committee on Public Works, 85th Cong., 2d Sess. 30 (1958) (hereinafter cited as 1958 Hearings).

5 S. Rep. No. 1407, 85th Cong., 2d Sess. 32 (1958). 
of roadside control, protested against "federal control of matters ... within the jurisdiction of the states." 6

In 1957 two bills designed to regulate outdoor advertising along the Interstate Highway System were submitted to Congress. Senator Neuberger again sponsored legislation designed to allow purchase of advertising rights, this time by the states, but allowing them use of federal funds to pay $90 \%$ of the cost.7 Also proposed was an administration measure whose salient feature would have penalized states not conforming to specified advertising control standards by reducing the federal share of highway expenditures from 90 to 85 percent. $^{8}$ After extensive hearings, the Public Roads Subcommittee of the Committee on Public Works approved an amended Neuberger bill; however, the measure was killed in the full committee by a 7-6 vote.

\section{Regrouping and success}

A plethora of advertising control bills descended on Congress in 1958. The concept of incentive payments, rewarding states which complied with defined national standards, was incorporated into Senator Neuberger's bill, S. 963.9 Legislation sponsored by Senators Prescott Bush and Joseph Clark rehed on incentive payments, and also allowed use of a limited percentage of the federal share of total highway cost to be used for purchase of advertising rights. ${ }^{10}$ Senator Thomas Kuchel of Cahifornia, who had voted against the Neuberger bill in 1957, at this juncture proposed his own bill, S. 3218, which provided incentive payments but did not allow use of federal funds in the purchase of advertising rights. ${ }^{11}$ During the conduct of the hearings, at the suggestion of Senator Albert Gore, ${ }^{12}$ Chairman of the Subcommittee on Public Roads, Senators Neuberger and Kuchel composed the differences of their bills and presented legislation relying on the declaration of a national policy in favor of controlling roadside advertising, standards to gnide this control, promulgation of supplementary regulations by the Secretary of Commerce, agreements between state officials and the Secretary of Commerce specifying the actual scope of control, and incentive payments for conforming states. ${ }^{13}$ After passage by the subcommittee, this new bill was amended and passed in a 7-6 vote by the full committee, and after further amendments and a bitter floor debate in the Senate,

6101 Cong. REc. 5785 (Daily ed. May 23, 1955).

7 Hearings on S. 963 Before a Subcommittee of the Senate Committee on Public Works, 85th Cong., 1st Sess. 1 (1957) (hereinafter cited as 1957 Hearings).

8 See id. at 5.

91958 Hearings 2.

$10 I d$. at 3. The Hale Bill, H.R. 9657, 85th Cong., 2d Sess. (1958), was an identical measure introduced in the House of Representatives.

111958 Hearings 4. Senator Kuchel's previous opposition stemmed from his doubts concerning the constitutionality of the proposed legislation. His proposal was intended to obviate his own and other's doubts by giving the states initiating power to participate in the programs and to protect prior state and inunicipal zoning action.

121958 Hearings 43.

${ }^{13}$ At this stage in the history of the bill there was no provision for allowing use of federal funds in the purchase of advertising rights by the states. The bill reported out of coinmittee to the Senate floor did, however, provide for linited federal participation to accomphish this purpose. 
was finally approved in both houses and signed into law by President Eisenhower on April 16, 1958.14

\section{II}

THE STATUTE, THE REGULATIONS AND THEIR IMPLICATIONS

\section{Scheme of action}

Section 131 places the responsibility for regulation in the hands of the individual states, thereby maintaining a state-federal relationship common to all the federal aid highway bills. ${ }^{15}$ Although decried by its opponents as a blatant attempt by the federal government to occupy a traditional area of state responsibility, $^{16}$ the ineasure carefully relies on state action to accomplish its purposes. $^{17}$ There will be no control of roadside advertising along the Interstate System in a particular state unless that state chooses to comply with the standards set by the statute and the regulations. Any decision on compliance with these standards will require understanding of the statute and regulations, and the purpose of this section of the comment is to detail these specifics in the context of possible state action.

\section{A national policy}

By force of section 131 it is now a national policy of the United States, ${ }^{18}$ "that the erection and maimtenance of outdoor advertising displays, or devices within six lundred and sixty feet of the edge of the right-of-way and visible from the main traveled way of all portions of the Interstate System constructed upon any part of right-of-way the entire width of which is acquired subsequent to July 1,1956 , should be regulated, consistent with national standards . . . .10

14 Letter from Dwight D. Eisenhower to Maj. Gen. U.S. Grant 3rd (ret.), Jan. 15, 1958, in Cong. Q. WeEkty REP. 100 (1958). For the President's remarks in signing the bill see Linde, Mentorandum for roundtable discussion on "Civilizing the American Roadscape" at Yale University, May 1, 1958, in 104 Cong. Rec. 7614 (daily ed. May 13, 1958).

15104 Cong. Rec. 4539 (daily ed. March 24, 1958); 104 Cong. Rec. 4663 (daily ed. March 25, 1958). "Federal" highways are in fact built by the states which must comply with federal standards in order to become ehgible for federal funds. Good precedents for this type of legislation exist in the Dingell-Johnson Act (Fisheries), 64 Stat. 430 (1950), 16 U.S.C. \& 777 (1952), and the Pitman-Robertson Act (Wildlife), 50 Stat. 917 (1937), 16 U.S.C. \& 669 (1952).

16104 Cong. Rec. 4834 (daily ed. March 26, 1958).

17 Although it may be constitutionally feasible to enact direct federal control of billboards, and such was in fact urged, 1958 Hearings 30 , this course was not taken. 104 Conc. REC. 4847 (daily ed. March 26, 1958). Possible arguments to sustain direct federal control considering the highways as instruments of interstate commerce, can be made under the commerce clause, 1957 Hearings 44, and the congressional power over national defense; id. at 345 .

18 The introductory language of $\$ 131$ states that the object of the bill is, "To promote the safety, convenience, and enjoyment of public travel and the free flow of interstate commerce and to protect the public investment in the National System of Interstate and Defense Highways ... ."72 Stat. 904 (1958), 23 U.S.C.A. \$ 171a (Supp. 1958). By this language the legal basis for federal legislation is set forth. In addition, this introduction sets an example which the states might well follow in order to lay a firm basis for the exercise of their police power in the actual regulation of billboards. Thus the concept of public welfare is suggested by the phrase, "safety, convemience, and enjoyment of public travel." Public welfare as a basis for exercise of state police power here reduces itself to considerations of aesthetics and safety. This coinment will explore the possibilities of their use, see text at note 117 infra.

1972 Stat. 904 (1958), 23 U.S.C.A. \$ 171 (a) (Supp. 1958). The final regulations proinulgated by the Secretary of Commerce under the authorization of $\S 131$ are found at 23 Fed. Reg. 
This national policy is to be effectuated through a series of agreements between state highway officials and the Secretary of Commerce. The terms of the agreement are to be controlled by the standards specified in section 131 itself and by regulations promulgated by the Secretary of Commerce. The purpose of the policy is to regulate, not to prohibit advertising along the Interstate System, ${ }^{20}$ and a study of the history of the bill shows the clear intent that standards be adopted which are flexible enough to protect the legitimate right of roadside service businesses to inform travelers of their existence while holding to a minimum the interference with travelers' enjoyment of scenic beauty occasioned by display advertising. ${ }^{21}$ The ultimate usefuhress of the legislation must be judged by its success in balancing these interests.

One provision of section 131, the so-called Cotton Amendment, appears to hamper effectuation of the national policy. This amendment limits the effect of the incentive program to right-of-way, the entire width of which was acquired subsequent to July $1,1956 .{ }^{22}$ Present estimates are that from $25-35 \%$ of the right-of-way acquired for the Interstate System will not qualify for incentive participation under this provision. ${ }^{23}$ And it appears inevitable that the system will incorporate random stretches of non-qualifying rights-of-way. If states act

8793 (1958), 23 C.F.R. \$ 20.1-20.10 (1958). The regulations define "sign" at $\$ 20.2(\mathrm{~m})$, "visible" at $\S 20.2(\mathrm{~s})$, and "main-traveled way" at $\S 20.2(\mathrm{j})$. The regulations are reproduced im appen$\operatorname{dix} B$ following.

Since prohibited signs are defined in $\$ 20.2(\mathrm{~m})$ in terms of the advertising message being visible from the main-traveled way, quaere whether the effect of the statute is limited to regulating only signs the advertising message of which is visible to the interstate highway traveler, thus allowing the erection of signs facing frontage roads the backs of which are visible to the traveler. It is to be noted that "main-traveled way" does not inelude frontage roads. Id. at $\$ 20.2(j)$. Such a construction of the statute would seem to defeat its obvious intent. The backs of signs facing on frontage roads are clearly as objectionable from the standpoint of blocking the view as are signs fronting on the main-traveled way. However, such a result is consistent with a policy of only controlling advertising in relation to the Interstate System.

20104 Cong. REc. 4645 (daily ed. March 25, 1958).

21104 Cong. REc. 4540 (daily ed. March 24, 1958).

22 This language gives rise to what will in all probability be the most significant factor in minimizing the application of the statute. Named for its mentor Senator Norris Cotton of New Hampshire, the Cotton Amendment was introduced on the Senate floor with the intention of limiting the effect of the bill to those portions of the Interstate System that were newly acquired in order to protect all existing advertising along presently acquired right-of-way that will be incorporated into the system. 104 CoNc. REc. 4845,4863 (daily ed. March 26, 1958). It has been called by some a major breach in the regulatory scheine, 104 CoNG. REc. 4863 (daily ed. March 26, 1958), and, moreover, it appears that for the most part its intent will not be realized since in almost all cases where existing rights-of-way are being widened billboards will in fact have to be removed.

The wide application which the Cotton Amendment will have may best be seen from the manner in which the regulations expound its mandate. \$ 20.2 (a) defines "acquired" to include donation, dedication, purchase, condemnation, use, or otherwise. Furthermore under $\S 20.2$ (c) (1), "a portion shall be deemed so constructed if, within such portion, no line normal or perpendicular to the centerline of the highway and extending to both edges of the rigbt-ofway will intersect any right-of-way acquired for right-of-way on or before July 1, 1956." However, the practical effect of this exemption may be lessened in that the other major exceptions to the bill's effect, i.e., areas zoned industrial or commercial by state law and areas traversing incorporated municipalities not subject to state zoning laws, will often coincide with the parts of the system acquired before July 1, 1956.

23104 Conc. Rec. 4863 (daily ed. March 26, 1958). 
to control only the qualifying portions, a checkerboard pattern of advertising will result. However, the standards set by section 131 and the regulations are minimal. A state is free to enact more stringent regulations. ${ }^{24}$ Therefore, it seems desirable that states control, where possible, portions of the system necessary to obviate this checkerboard effect. Although a state can not qualify an area acquired prior to July 1, 1956 for incentive payments by thus controlling it, federal funds can be made available for the acquisition of advertising rights. ${ }^{25}$

\section{Standards for regulation}

The general policy of the standards is to exclude brand-name advertising, while making available to Interstate Highway travelers information concerning off-highway facilities, particularly sleeping and eating accommodations, tourist resorts, and automotive supply and repair services. ${ }^{26}$ Section 131 sets up four roughly drawn categories of signs permissible within 660 feet of the edge of the right-of-way, an area characterized by the regulations as "the protected area,"27 and leaves to the regulations the difficult task of drawing the fine lines of definition. ${ }^{28}$

The first enumerated, and most obvious, class of sigus allowed within the protected areas consists of "directional or other official signs or notices that are required or authorized by law."29 It appears to have been the intent of Congress to include only traffic control and, possibly, mileage signs within this group. ${ }^{80}$ The regulations limit Class (1) sigus to those actually erected and maintained by public officials pursuant to state or federal law for the purpose of carrying out an official duty. ${ }^{31}$ This specification avoids an interpretation of "authorized"

24 See 23 Fed. Reg. 8795 (1958), 23 C.F.R. $\$ 20.10$ (1958).

25 Due to the Cotton Amendment a state is not entitled to an incentive bonus for controlling advertising on portions of the Interstate System acquired prior to July 1, 1958. 104 Cono. Rec. 4863 (daily ed. March 26, 1958). A state is, however, entitled to its $90 \%$ federal share of that portion of the cost of acquiring advertising rights which does not exceed $5 \%$ of the total cost of the right-of-way for the project. This latter provision is found in subsection (e) of the act and is considered applicable to lands otherwise exempted by the Cotton Amendment since under this provision there is no requirement of an agreement between the state and the Secretary of Commerce. Id. at 4867 .

20104 Cong. Rec. 7613 (daily ed. May 13, 1958).

27 The regulations define "protected areas" to mean, "all areas inside the boundaries of a State which are adjacent to and within six hundred sixty feet of the edge of the right-of-way of all controlled portions of the Interstate System within that State." 23 Fed. Reg. 8794 (1958), 23 C.F.R. \& 20.2(k) (1958).

28 It is to be noted that the regulations are to include only the four classes of signs permitted by the statute and no signs advertising illegal activities. 72 Stat. 904 (1958), 23 U.S.C.A. $\$ 171$ (a) (Supp. 1958). This restriction was added as a perfecting amendment on the Senate floor at the imsistence of Senator Joseph O'Mahoney wbo felt that without such a restriction the statute might be taken as permitting the Secretary of Counmerce to authorize additional classes of signs and therefore be held unconstitutional as an excessively broad delegation of authority. 104 Cong. REc. 4875 (daily ed. March 26, 1958).

Quaere whether "illegal activities" can be broadened to include signs advertising illegal products since such signs are generally designed to promote the sale or distribution of such products and therefore relate to an activity? U.S. BUREAU OF PUBLIC ROADS, DEPT. OF COM-

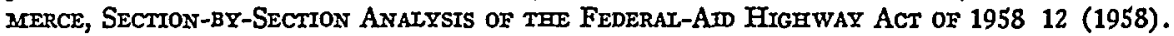

2972 Stat. 904 (1958), 23 U.S.C.A. \& 171(a) (Supp. 1958).

30104 Conc. Rec. 4539 (daily ed. March 24, 1958).

31 See 23 Fed. Reg. 8794 (1958), 23 C.F.R. \$ 20.5(a) (1958); 1958 Hearings 40. 
which might have allowed state designation of "official" but privately sponsored signs $^{32}$ to escape the limitations imposed on Class (3) and (4) signs..$^{33}$

The second category of permissible signs encompasses, "signs advertising the sale or lease of property upon which they are located."34 This authorization is one thought necessary in fairness to landowners, ${ }^{35}$ and it is wisely limited by the regnlations to, "not more than one such sign ... as to be visible to traffic proceeding $\mathrm{m}$ any one direction ....'36 Congressional debate clearly" indicates that Class (2) signs were to be himited to signs dealing with the sale or lease of the real property upon which they were located. ${ }^{37}$ The regulations expand the intended scope of the class by mcluding signs advertising activities being conducted on the premises. ${ }^{38}$ It appears that Congress did not intend to exclude signs which recited only the name of a roadside business establishment, ${ }^{39}$ and the expansion of Class (2) may have been intended to accommodate these "identifying" signs. However, the regnlations apply trade name advertising rules which, due to their laxness, allow general advertising displays to be erected under this category. ${ }^{40}$ It would appear to have been more consonant with Con* gressional intent to have restricted Class (2) to signs advertising the sale or lease of the real property upon which they are located and to signs identifying the activity on, or near which, they are located. ${ }^{41}$

Before discussing Class (3) and (4) signs, it is necessary to consider the provisions of the regulations establishing Information Rest Areas on the Interstate System. ${ }^{42}$ The inclusion of roadside rest areas in modern highway planning is a widely accepted concept; ${ }^{43}$ however, the idea of utilizing these areas to

32 Where it was intended to allow a state to authorize by positive enactment the erection of signs by private groups, the words, "pursuant to authorization in state law," were used in Class (4). 104 Cong. REc. 4539 (daily ed. March 24, 1958). Where it was intended to allow, subject to the standards to be promulgated by the Secretary, signs neither prohibited nor expressly authorized by state law, the words, "pursuant to authorization or permitted under state law," were used in Class (3). 104 Cong. REc. 4885 (daily ed. March 26, 1958). Thus use of the words, "required or authorized by law," in Class (1) must be taken to mean only official signs erected by public officers or agencies under authority of state law. 104 CoNG. REc. 4539 (daily ed. March 24, 1958).

33 An example of such a privately sponsored sign might be one erected by a municipality to attract travelers, i.e., 32 Motels in Homeville. Obviously, if sucl were considered an "official" sign the restrictions imposed by Class (3) and Class (4) would largely be rendered ineffective.

3472 Stat. 904 (1958), 23 U.S.C.A. \$ 171 (a) (Supp. 1958).

35104 Cong. Rec. 4539 (daily ed. March 24, 1958).

3023 Fed. Reg. 8794 (1958), 23 C.F.R. $\$ 20.5$ (a) (1958).

37104 Cong. Rec. 4882 (daily ed. Marcl 26, 1958).

3823 Fed. Reg. 8794 (1958), 23 C.F.R. $\$ 20.5$ (a) (1958). The regulations treat Class (2) signs advertising activities located on or within fifty feet of the activity as a subcategory. As to this subcategory there is no himitation of size and no brand name restriction. See $\$ 20.8(\mathrm{~g})$, 20.5(b). Class (2) signs advertising activities and located more than 50 feet from that activity are governed by the same size and brand name restrictions as are Class (3) and (4) signs, discussed starting at text at note 56 infra.

391958 Hearings 51.

40 See note 38 sicpra.

41 All Class (2) signs are further expressly regulated as to their construction and positioning by the general provisions of $\$ 20.8$.

4223 Fed. Reg. 8794 (1958), 23 C.F.R. \$ 20.6 (1958).

43 The original authorization of roadside rest areas on federal highways dates back to 1940. 54 Stat. 870 (1940), 23 U.S.C. $\$ 10($ b) (1952). 
dispense traveler information was first accepted by the regulations. ${ }^{44}$ These sites will incorporate the usual facilities found in roadside rest areas, e.g., parking area, picnic tables and benches, toilets, and water, with signboards featuring advertising displays which fit within Class (3) and (4) classifications. ${ }^{45}$ The plan envisions allowing businesses near the highway to inform travelers of their location and facilities, while at the same time getting the driver off the high speed highway while he looks for services and accommodations. Although the scheme will require habit formation among travelers, it appears to have promise as an effective compromise of the businessman's need to reach the traveler and the traveler's need for information. It also provides a means of containing the effect of Class (3)'s provisions allowing all businesses located within 12 miles of the highway to advertise along the Interstate System.

Class (3) signs are defined in section 131 as, "signs erected or maintained pursuant to authorization or permitted under State law, ${ }^{46}$ and not inconsistent with the national policy and standards of this section, advertising activities being conducted within 12 miles of the point at which such signs are located." 47 The scope of Class $(3)^{48}$ was greatly enlarged in the committee debate, ${ }^{40}$ and this expansion caused an overlap of Class (3) and (4) signs. The regulations, by expanding the coverage of Class (2),,$^{\text {to }}$ cause an overlap of all three categories. That is, signs in the specific interest of the traveling public [Class (4)] ${ }^{61}$ may also be either signs advertising activities being conducted on the property on which the signs are located [Class (2)], or signs advertising activities located within twelve miles of such signs. It thus became necessary for the regulations

44104 Cong. Rec. 7614 (daily ed. May 13, 1958). The first suggestion of use of Informational Sites in conjunction with $\$ 131$ appears to have been made by Mr. Hans Linde, Legisla. tive Assistant to Senator Neuberger in a speech given at Yale University. Linde, Memorandum for Roundtable discussion on "Civilizing the American Roadscape," May 1, 1958. See 104 Cowo. Rec. 7614 (daily ed. May 13, 1958).

45 The sites will be established in accordance with the regulations for the administration of federal aid for highways. Their location and frequency shall be as determined in the agreements between the Secretary of Commerce and the State Highway Department. The Class (3) and (4) signs permitted at the sites must be placed on large panels the maximum size of which cannot exceed thirteen feet in height and twenty-five feet in length, imcluding border and trim but excluding supports. The individual signs to be placed on the panels cannot exceed twelvo square feet in area, and each activity is permitted only one sign within the Informational site. Moving signs and illumination by other than white light is not permitted. 23 Fed. Reg. 8794 (1958), 23 C.F.R. \$ 20.6 (1958).

46 See note 32 supra.

4772 Stat. 904 (1958), 23 U.S.C.A. § 171 (a) (Supp. 1958).

4823 Fed. Reg. 6679 (1958), 23 C.F.R. $\$ \S 20.6,20.7$ (1958). It is to be noted that the regulations specify air miles and not highway miles as the mode of measurement.

49 The amalgamated bill sponsored by Senators Neuberger and Kuchel originally allowed only signs advertising activities being conducted on the premises upon which the signs were located. S. Rep. No. 1407, 85th Cong., 2d Sess. 48 (1958). This was changed in committee to, "Signs not larger than 500 square inches advertising activities being conducted at a location within 12 miles of the point at which signs are located." Id. at 38. On the Senate floor after graphic illustration of the difficulties attendant to reading a sign of such size, Senator Francis Case, who had originally proposed the size limitation in committee, offered a modifying amendment which eliminated the size restriction and at the same time added the language, "pursuant to authorization or permitted under State law, and not inconsistent with the national policy and standards of this section." This addition was designed to put restrictions on brand name advertising. 104 Cong. Rec. 4884 (daily ed. March 26, 1958).

50 See text at note 38 supra.

51 See text at note 52 infra. 
to establish rules dealing with the specific categories and with the overlapped portions of the categories. Before considering the results of their efforts in detail, it is necessary to discuss the nature of Class (4) signs.

Class (4) signs are those "erected or inaintained pursuant to authorization in State law and not inconsistent with the national policy and standards of this section, and designed to give information in the specific interest of the traveling public." T2 The original intent of this provision, which was not amended during the floor debate, appears to have been to allow erection of generally phrased informational notices similar to those used on the toll road systems found in many eastern and mid-western states. ${ }^{53}$

In order to determine the mileage and trade name advertising restrictions applicable to a given sign it is necessary to classify it within one or more of the permissible categories set by the statute and the regnlations. To facilitate an attack on the problem of classification an attempt will be made to consider the rnles made applicable to each category of signs.

\section{Class (3) signs}

Signs which quahify only under Class (3) are those which advertise activities not in the specific interest of the traveling public but which are located within twelve miles of the sign. If an mformational site is located within twelve miles of the activity being advertised, signs advertising the activity are restricted to that site. ${ }^{54}$ If no site is available within the twelve mile radius, a sign may be placed within the protected area, subject to general restrictions. ${ }^{55}$ When Class (3) signs are restricted to Informational sites, all sites located within a twelve mile radius of the activity may be utilized. ${ }^{56}$ Trade or brand names may be placed on these signs, but not more conspiculously than the name of the advertised activity. ${ }^{57}$

\section{Class (4) signs}

Signs quahifying only under Class (4) are those carrying a message deemed to be in the specific interest of the traveling public and located more than twelve miles from the activity which they advertise. The only mileage restriction imposed on such a sign limits the erection of such signs within the protected area to locations where an Informational site is not available within twelve miles. ${ }^{58}$ If no desirable location more than twelve miles from a site can be found, then Class (4) signs are restricted to Informational sites. Signs qualifying under Class (4) only, may be located within more than one Informational site, and there appears to be no restriction on the number of such signs, except that only

ธ2 72 Stat. 904 (1958), 23 U.S.C.A. § 171(a) (Supp. 1958). The intent behind establishing this class of signs was to give the states the widest possible latitude in developing themselves, or in authorizing private agencies to develop, signs necessary in the interest of the traveling public. 104 Cong. Rec. 4539 (daily ed. March 24, 1958).

53 1957 Hearings 362 .

54 23 Fed. Reg. 8795 (1958), 23 C.F.R. \$20.7(a)(1) (1958).

55 These restrictions relate to the number of signs which may be allowed per mile in advance of interchanges, $i d$. at $\S 20.7(\mathrm{~b})$; to their size, $i d$. at $\S 20.8(\mathrm{~g})$; to their construction characteristics, $i d$. at $\$ 20.8$; and to their condition, $i d$. at $\S 20.4$.

56 Id. at $\$ 20.6(\mathrm{~b})(5)$.

57 Id. at $\$ 20.5(\mathrm{~b})$.

68 Id. at $\$ 20.7$ (a) (2). 
one sign can be erected within any one site. ${ }^{58}$ When signs under this or any other category are permitted within the protected area, only one sign visible to traffic moving in any one direction on an Interstate Highway may be erected. ${ }^{00}$ The brand or trade name restrictions applicable here concern themselves with the type of trade name rather than the size of the lettering. Trade names characterizing a place or identifying vehicle service, equipment, parts, accessories, fuels, oils, or lubricants available at such a place are the only trade names permitted. ${ }^{61}$

\section{Signs qualifying under both Class (3) and (4)}

Signs of specific interest to the traveling public and located within twelve miles of the activity being advertised are subject, at the advertiser's election, to the mileage restrictions of either Class (3) or (4). ${ }^{62}$ Since the Class (4) mileage restrictions are less stringent, the result of the regulations' treatment of this overlapped portion will be to allow more signs within the protected area. However, this construction appears in harmony with Congressional intent to permit any business whose activities are located within twelve miles of the highway to advertise somewhere along the highway and to accord greater deference to those businesses which are most dependent upon travelers and which, accordingly, are of most interest to travelers. ${ }^{63}$ The regulations also provide that signs within this category, as with signs quahifying under Class (4), may be located within more than one Informational site, with no apparent restrictions on the number of sites which may be utilized. ${ }^{04}$ The owner of an activity qualifying under Class (3) and (4) is allowed, again at his election, to advertise under the trade name restrictions applicable to either Class (3) or (4). ${ }^{65}$

\section{Signs qualifying under Class (2) and under Class (4)}

A sign advertismg an activity conducted on the property on which the sign is located and whose message gives information in the specific interest of the traveling public is obviously not affected by mileage restrictions. Restrictions of trade name advertising are made to turn on both the sign's distance from the activity and whether it also qualifies under Class (4). Signs located within fifty feet of the activity are not limited as to size or quahity of message. ${ }^{60}$ Signs located nore than fifty feet from the activity are governed by the same size and trade name restrictions as are Class (3) signs. ${ }^{67}$ But in either case, if the sign also qualifies under Class (4), the advertiser can elect to be bound by the restrictions applicable to Class (4). ${ }^{88}$ The exact determination of which category to use will turn on the particular situation of the advertiser.

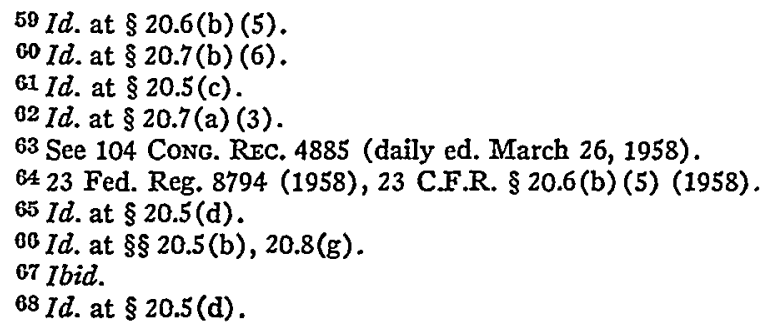




\section{The regulations and trade name restriction}

One of the primary aims of section 131 is to diminish general advertising displays. ${ }^{69}$ That principle has been steadily diluted to the point of allowing signs located within fifty feet of the activity which they are advertising to attain any size and to utilize any style of trade name advertising desired. ${ }^{70}$ It is apparent that the weakening of these restrictions has been influenced by a desire to allow an activity located near the highway to retain relatively unhampered use of its land. However, this policy apparently ignores a strong argninent that the use of general advertising near the highway is, in reality, an exploitation of a public investment. ${ }^{71}$ The regnlations' handling of brand or trade name advertising attempts to compromise the conflicting interests that have been at issue throughout the history of this piece of legislation, and except for the provisions just noted, they appear to have taken the middle ground between the extremes. It may be mentioned again that these restrictions are minimal, and that states may enact more stringent regulations if they choose. A possible, but extremely unlikely, method of state control could involve state prohibition of all specific advertising within the protected areas. Since allowance of all permissible classifications of signs is predicated on a lack of state prohibition, total prohibition, ${ }^{72}$ though subject to legal objections discussed below, ${ }^{73}$ is allowed under section 131 . Considering the legal objections and the strong economic pressures that will undoubtedly be brought before state legislators, complete prohibition appears unlikely.

\section{State-federal agreements}

Subsection 131 (b) authorizes the Secretary of Commerce "to enter into agreements with State highway departments ... to carry out the national policy ... ."74 These agreements are to include provisions for regnlation of advertising signs in conformity with the standards already considered. Since few, if any, state highway officials presently have authority to enter such agreements, state enabling legislation will be necessary. ${ }^{75}$ These agreements are not

68 See 104 Cong. Rec. 4884 (daily ed. March 26, 1958).

7023 Fed. Reg. 8794, 8795 (1958), 23 C.F.R. $\$ \S 20.5(\mathrm{~b}), 20.8$ (g) (1958).

71104 Cong. REc. 4541 (daily ed. March 24, 1958).

72 See note 32 supra.

73 See text starting at note 119 infra.

7472 Stat. 904 (1958), 23 U.S.C.A. \$ 171 (a) (Supp. 1958).

75 The views of those opposing the legislation in committee, as specified in the committee report, pointed out that state highway departments can have no authority to contract unless it is given by the state legislature. Furthermore, it was stated that Congress has no power to authorize the Secretary of Commerce to contract in regard to the regulation of uses to which private property may be put. Therefore, it was claimed, the act purports to authorize two parties, neither of whom have legal authority, to contract in relation to the property rights of a third party. S. REP. No. 1407, 85th Cong., 2 d Sess. 58 (1958). The answer to this, as is clear from reading subsections (b) and (c) of the act, is that no such thing is attempted, but rather that a state must authorize its highway department to contract. Moreover, the Secretary of Commerce is in reality contracting in relation to federal obligations, while the state officials are contracting in relation to state obhigations. The control of private property is included within the state obhgations, and the state action is predicated on a valid exercise of its police power.

It is clear that the statute contemplates one agreement covering many projects. Though supplemental agreements are recognized it is the original agreement that provides the key to payment of the incentive. 104 Conc. REc. 4651 (daily ed. March 25, 1958). 
limited to advertising control, and may include other provisions for making highway travel more enjoyable. ${ }^{76}$

In order to accommodate those states which were considered as unable to, and those states which do not wish to, regulate advertising within inunicipalities, section 131 (b) provides that "upon application of the State," the agreement may exclude from application of the national standards segments of the Interstate System "which traverse either inunicipally zoned land or land whose use is clearly established as industrial or commercial by state law." The intent of this section is to ensure that a state will not be excluded from participation in the program due to its inability to control municipally zoned land. ${ }^{78}$ In deference to problems raised by advertising control on land already zoned as industrial or commercial by the state, ${ }^{79}$ these areas are considered subject to exclusion. However, no area which is withdrawn from application of the national standards can be considered in computing the incentive payment. ${ }^{80}$ These exclusions are inade subject to the discretion of the Secretary of Commerce who is to be guided, apparently, by the general policies of the statute. ${ }^{81}$ There are no restrictions placed on the quantum of state control by the provision, and states may control advertising, if they so wisl and are legally competent, for the entire length of the Interstate System within their state. The scheme is one of accommodation, not of compelling state legislation.

\section{Incentives for compliance}

As to the portions of the Interstate System subject under agreements to the national standards, the federal share of the total cost of such portion will be increased from $90 \%$ to $90 \mathrm{I} / 2 \% .^{82}$ These agreements must be entered into before

76 "among other things provisions for preservation of natural beauty, prevention of erosion, landscaping, reforestation, development of viewpoints for scenic attractions that are accessible to the public without charge, and the erection of markers, signs, plaques, and the development of areas in appreciation of sites of historical significance." 72 Stat. 904 (1958), 23 U.S.C.A. §171a (Supp. 1958). It is to be noted, however, that except as provided by subsection (e) of the act (relating to the acquisition of advertising rights) federal funds may not participate in roadside development and landscape preservation except as already provided for by section 11 of the Federal Highway Act of 1940. 54 Stat. 870 (1940), 23 U.S.C. $\$ 10$ (1952).

77 The initiative for obtaining exclusion is thus placed in the hands of the state, and it appears clear that Congress intended that the Secretary of Commerce will allow exclusion of sections of the system when a state makes a good faith determination that it cannot or should not regulate land within municipalities. See dehate at 104 Cong. Rec. 4646 (daily ed. March 25, 1958) ; 104 Cong. Rec. 4868 (daily ed. March 26, 1958). Section 20.9 of the regulations would appear when read literally to give the Secretary tremendous discretion in deciding upon exclusion, but it is considered that these provisions must be read in the light of the congressional debate noted above.

78104 Conc. Rec. 1335 (daily ed. Feb. 3, 1958), 1958 Hearings 9.

79 The problems of retroactive zoning are considered in text at note 156 infra.

80 This is the amendenent sponsored on the Senate floor by Senator Case of South Dakota who desired to inake certain that areas not meeting the federal standards would be excluded in computing the incentive payments. Senator Gore stated that this amendment only restated a reasonable interpretation of the bill, but accepted it as a perfecting amendment. 104 Conc. REC. 4839, 4861, 4869 (daily ed. March 26, 1958).

81 See note 77 supra.

8272 Stat. 904 (1958), 23 U.S.C.A. \& 171(a) (Supp. 1958). It appears that the bonus may be used by the states in any way they see fit. In all probability it will be used for roadside development and beautification, or for defraying the cost of carrying the agreement into effect since this part of the cost is excluded in computing the bonus. Ibid. The increased federal share is payable only from momies appropriated and not from the highway trust fund 
July 1, 1961 in order to qualify projects of the system for incentive payments. ${ }^{83}$ Therefore, state legislation must be promptly considered if highway officials are to have time to reach a thoroughly satisfactory agreement with the Secretary of Commerce. The amount of money any particular state will save by entering an agreement is, due to the exclusions of the Cotton Amendment and of previously zoned areas, highly speculative. ${ }^{84}$

\section{Federal participation in cost of acquiring advertising rights}

The final provision of section 131 to be considered authorizes federal participation, on the $90-10$ share basis, ${ }^{85}$ in the cost of acquiring advertising rights along the Interstate System. However, this participation is limited to such portions of the cost which do not exceed $5 \%$ of the cost of the right-of-way of each project, ${ }^{86}$ excluding the additional costs incurred in acquiring advertising rights. This offer of participation is not limited to areas subject to state-federal agreements but can be invoked "whenever a state acquires, by purchase or condemnation the right to advertise or regulate advertising in an area adjacent to the Interstate System."

The combination of this offer of federal participation with the incentive payments program, the national policy and standards concept, and the administrative regulation and agreement making program represents a packaging of the major techniques of advertismg control that were suggested to Congress. Despite some deficiencies just considered, the statute and regulations appear to afford a flexible and effective plan of achievement of their announced intention.

\section{III}

\section{STATE LEGISLATION: DISCUSSION AND ANALYSIS}

Perhaps the best way of determining what a state must do in order to comply with the federal act and gam the incentive bonus is to consider existing state

as the sponsors of the act had originally intended. 104 CoNG. Rec. 4540 (daily ed. March 24, 1958). For an analysis on the subject of the highway trust fund see, U.S. BurEaU of PuBzic Roads, Dept. of Connarere, Section by Section Analysis of the Federal-Am Higitway ACT of 195816 (1958).

83 The projects eligible include those which have been counpleted and on which the federal share has been paid before the agreement was entered into, or those completed before enactment of the statute. See S. REp. No. 1407, 85th Cong., 2d Sess. 39 (1958). It appears that states which have already passed sufficient legislation will be eligible for the bonus since it accrues as a result of signing the agreement with the Secretary of Commerce and not merely for regulating advertising alone. This should effectively meet the doubts as to the eligibility of states with existing sufficient legislation that were raised in the separate views of the committee report. Id. at 58 .

84 See Ohio Legrsiattve Service Comanssion, Problenss Pertanning to Regulation of Outdoor Advertising Along the Interstate Higriways 16 (1958). The provision for incentives is effective notwithstanding section 2 of the Federal-Aid Highway Act of 1944, added by ch. 626,58 Stat. 838 (1944), which provides: "the Commissioner of Public Roads shall not as a condition of approval of any project for federal aid hereunder, require any state to acquire title to, or control of, any marginal land along the proposed highway in addition to that reasonably necessary for road surfaces, median strips, gutters, ditches, and side slopes and sufficient width to provide service roads for adjacent property to permit safe access at controlled locations ...." For a criticism of the expansion of federal control applicable to the present act see 1957 Hearings 211.

85 Id. at 255 .

86 It is contemplated that though there will be a number of projects in each state there will be only one agreement. 104 Cong. REc. 4651 (daily ed. March 25, 1958).

87104 Cong. Rec. 4867 (daily ed. March 26, 1958). 
legislation. Laws regulating billboards along the Interstate System have already been enacted by Maryland, ${ }^{88}$ Ohio, ${ }^{80}$ Vermont, ${ }^{90}$ and Virginia. ${ }^{01}$ In addition, the Rhode Island ${ }^{92}$ legislature considered but did not adopt a proposal for signboard regulation. This latter attempt illustrates the danger of simple prohibition. The Rhode Island bill merely declared it unlawful to erect and maintain a billboard withm 660 feet from the right-of-way line of the Interstate System within the state. Enforceinent was to be handled by imposing fines for violation. This rather naive measure was obviously loaded with difficulties which no doubt accounted for the legislature's failure to enact the bill into law.

\section{Existing state legislation}

Of the existing state laws the Maryland and Virginia acts are clearly inadequate to meet the federal requirements. In Maryland the regulated area extends only 600 feet from the edge of the right-of-way and in Virginia only 500 feet. The Virginia statute, like the Rhode Island proposal, prohibits signs within the protected area, but it contains a long list of exceptions the most objectionable of which allows businesses offering services to travelers and located within 10 miles of the right-of-way to erect four signs within one mile of the interchange serving their location. The Maryland act in spite of its present inadequacy shows more imagination. It prohibits landowners within the 600 foot limit from permitting the erection of billboards after the effective date of the act. Billboard leases made prior to the effective date of the act are to become null and void on June 1,1961, unless they are to run longer than three years past the effective date of the act. Then these leases are to be acquired by purchase or condemnation.

The Ohio and Vermont laws would appear to meet the requirements of the federal act. The Ohio statute regulates the area within a distance of 660 feet from the edge of the right-of-way, prohibiting the erection and maintenance of billboards. Stated exceptions to this prohibition generally conform to those in the federal act. Advertising devices maintained in violation of the law are declared to be a public nuisance removable, after notice to the offending party, by court order upon complaint of the director of public highways. Violations are also punishable by fines. Finally the director of highways is given authority to enter into agreements with the Secretary of Commerce and to accept any allotment of funds made under the federal act. The Vermont statute controls advertising to a distance of 750 feet from the Interstate right-of-way by means of a direct prohibition of advertising displays, with exceptions generally conformable to those in the federal act. The Secretary of State may remove a nonconforming sign upon failure of the offending party to comply with a removal order. A further sanction of fine or inprisonment is also provided. The act does not, however, authorize the state highway department to contract with the Secretary of Commerce, and this may occasion some difficulty.

\section{Requirements of state action}

The foregoing discussion of state legislative attempts illustrates that there are many methods of comphance with the federal act which California might

\footnotetext{
88 LAwS OF MARYLAND, ch. 76, art. 89B § 231 (Supp. 1958).

89 OHIO Rev. Code, \$ 5515.21 (Supp. 1958).

90 Vermont Laws, No. 275 (1957).

01 CODE OF VIRGINIA, \& 33-298 (Supp. 1958).

92 Rhode Island January Session 1958, S. 493.
} 
choose. This comment does not attempt to suggest specific legislative measures, but instead has been directed toward outlining the requirements of the act. The second major consideration undertaken by this comment will center about legal difficulties which any state, and in particular California, may encounter in attempting comphance with the federal act. However, there should first be considered some specific pitfalls which any legislative effort in California must avoid. First, the agreement between the state highway department and the Secretary of Commerce must be entered into before July 1, 1961. This calls for early action by the legislature so that the time required for drawing up the agreement will be available. The California state highway official in question must be given authority to negotiate the agreement in behalf of the state. Secondly, the California law must conform to the minimum requirements of the federal statute and regulations thereunder. For instance the area to be regulated must extend at least 660 feet from the edge of the right-of-way. It is not necessary that a state duplicate exactly the standards of the federal act and regulations, but it must not do less. ${ }^{93}$ Finally, the legislature may indicate its views on the subject of Information Rest Areas, landscaping, areas subject to municipal land use control, and areas zoned commercial or industrial by state law. ${ }^{94}$ Alternatively, these matters may be left to the highway officials. There are also the obvious considerations of choice of sanctions, e.g., will the state rely on penalties, removal orders, or both? Also vitally important is the exact manner of regulation-by outright prohibition, a system of licensing, ${ }^{95}$ or otherwise. The state also must determine the method or methods of land use control to be pursued in attaining its objective.

\section{IV}

\section{LAND USE CONTROL AND THE BILIBOARD}

As noted previously the statute clearly places the responsibility for control of outdoor advertising in the hands of the individual states. It was the intent of the Committee on Public Works that participating states use whatever methods they felt were appropriate so long as the standards of the statute and the regulations of the Secretary of Commerce are met.96 Therefore it is necessary to consider the methods of land use control available to the states and their attendant advantages and disadvantages. Generally, the states in instituting their regulatory program are free to use condemnation of advertising rights, either prior or subsequent to acquisition of the right-of-way; zouning, which may be either comprehensive or confined to the roadside; or commercial purchase, either of the fee or of the advertising rights. In all probability many states will find it both necessary and expedient to use a combination of these methods.

93 It is clear that the federal act only sets minimum standards, and that a state can impose stricter control of roadside advertising if it wishes. 104 Cong. Rec. 4540 (daily ed. March 24, 1958).

04 For a discussion of the problems facing a state in attempting to comply with the federal act see Omo Legislative Service Commisston: Problems Pertaining to Regulation of Outdoor Advertising Along the Interstate Highways (1958).

05 In California the safeguards imposed on the licensing process by the administrative procedure act would appear to make that method more desirable. CaI. Govt. CoDE \$\$ 11500-11529.

88 S. REP. No. 1407, 85th Cong., 2d Sess,, 49 (1958). 


\section{Consideration of the condemnation device}

The use by the states of the condemnation device is expressly approved by subsection (e) of section 131, which provides for federal participation up to $5 \%$ of the cost of acquiring right-of-way whenever the state acquires by purchase or condemnation the right to advertise. ${ }^{97}$ Debate in Congress indicated that this section only applies to acquiring easements and not to the acquisition of the land in fee.88 This does not, however, preclude states wishing to condemn the fee in order to control advertising from doing so.

The inethod of excess condemnation is available.

Excess condemnation is the practice of taking more property than physically necessary for the creation of a public improvement and subsequently selling or leasing the surplus. It provides an effective means of controlling the development of an area immediately surrounding the public improvement since the condemner can sell or lease subject to any restrictions which it deems desirable. Furthermore since compensation which the condemner pays for the acquisition of the property is generally considerably less than the value of the property after the creation of the improvement the profits thus realized aid in defraying the cost of the improvement itself. 80

Therefore, a state desiring to use this method is not financially precluded from doing so merely because the federal reimbursement only goes to the cost of acquirmg the advertising right. The device may not practically be feasible, however, since severance damages will have to be considered, and furthermore the state may not be able to resell all the land at a profit. The advantages of excess condemnation are the obvious ones of providing good roadside development and recoupment of part of the cost of acquiring the right-of-way. Still there are disadvantages to use of excess condemnation. Large amounts of money must be spent initially, and it results in removal of land from the tax rolls, at least temporarily. Furthermore, courts using the narrow test of public use have occasionally outlawed it as violating the requirement that the taking must be for a public use. ${ }^{109}$ However, within the last 15 years it appears that no state court has so held. ${ }^{101}$ The United States Supreme Court has ruled against use

8772 Stat. 904 (1958), 23 U.S.C.A. § 171(a)(Supp. 1958). If the entire width of the riglit-of-way is acquired subsequent to July 1,1956 , then the state may qualify for the incentive bonus in addition to the provisions of subsection (e) of the act. 104 CoNG. REC. 4865 (daily ed. March 26, 1958). If, however, the right-of-way has been acquired prior to July 1, 1956 , then, of course, only the provisions of subsection (e) are applicable.

88104 Conc. Rec. 4541 (daily ed. March 24, 1958); 104 Conc. REc. 4663 (daily ed. March 25, 1958).

${ }^{89}$ Comment, 58 Yare L.J. 599, 606 (1948). The California Constitution as well as the constitutions of Mass., Mo., N.J., Ohio., Pa., R.I., Va., and Wis., authorize excess condemnation. In California the maximum possible limit that can be condemned using this method is 200 feet from the closest boundary of the public improvement. CAL. ConsT. art. I, § 141/2 (1928). Therefore excess condemnation would not be available in California to meet the requirements of the act unless by constitutional amendment its area of application were widened. Some states are not so limited. The Ohio Constitution in article XVIII section 10 provides for excess condemnation generally ratler than prescribing definite limits.

100 In re Opinion of the Justices, 204 Mass. 607, 91 N.E. 405 (1910); Pennsylvania Mut. Life Ins. Co. v. City of Plilladelphia, $242 \mathrm{~Pa} .47,88$ Atl. 904 (1913); City of Richmond v. Carneal, 129 Va. 388, 106 S.E. 403 (1921). A California court would not so hold since in California the use need only be beneficial to the public; there is no requirement of a right of use by the public. Redevelopment Agency v. Hayes, 122 Cal. App. 2d 777, 266 P.2d 105 (1954).

101 Comment, 58 YaIE L.J. 599, (1948). The modern trend in defining "public use" is well exemplified by Berman v. Parker, 348 U.S. 26 (1954). 
of excess condemnation where its sole purpose was to recoup expenses from the increased value of the excess upon resale, ${ }^{102}$ but it would seem that condemnation of road bordering lands for the protection of highway facilities could well be sustained upon an adequate presentation of the facts.

To avoid the difficulties inherent in excess condemnation a state may instead decide to condemn merely the advertising rights of land adjacent to the highway. This alternative would seem to be the most practical if the right-of-way has already been condemned, and will normally be the device pursued after an unsuccessful attempt to purchase the rights. The main problem encountered here is whether such rights are an interest entitled to compensation. Though not free from doubt, ${ }^{103}$ it would seem that the highway abutter's right of view is an interest in land ${ }^{104}$ in the nature of an easement appurtenant. ${ }^{105}$ There is some indication, however, that his compensable interest extends only to the destruction of his right to advertise activities being conducted on the premises, and that he may not be entitled to compensation for loss of his right to lease display advertising sites. ${ }^{106}$

Another problem that must be faced either in condemnation of the fee or merely of the advertising rights is whether the taking of property for billboard control purposes is a taking for a public use. In cases relating to direct prohibition of billboards under the police power it is often held that prohibition cannot be legally achieved without compensation. ${ }^{107}$ However, this does not mean that prohibition could necessarily be achieved with compensation. Indeed serious doubts have been expressed as to whether this can be done, ${ }^{108}$ and cases may be found holding that condemnation for the purpose of protecting the view and appearance of a highway is not a taking for a public use. ${ }^{109}$ However, the law today appears to be that the public use limitation on eminent domain requires only a purpose beneficial to the public and not a right of use in the public. ${ }^{110}$ There are numerous cases supporting condemnation for billboard control purposes, ${ }^{111}$ and in California it appears that the excess condemnation provision of Article I, section 14I/2 of the California Constitution sanctions by implication the taking of private property under eminent domam if it is needed to protect a parkway and to preserve its view, appearance, light, air, and usefulness. ${ }^{112}$ The state legislature normally declares in detail the types of

102 Cincinnati v. Vester, 281 U.S. 439 (1930).

103104 Cong. Rec. 4834 (daily ed. March 26, 1958).

1042 Nichols, Emitnent Domatn $\S \S 6.2,6.3$ (1958); Comment, 17 OHIo St. L.J. 116, 123 (1956).

1052 Nichors, EMrnent Dodrans $\$ 5.72$ (1958); Wilson, Billboards and the Right to Be Seen From the Highway, 30 GEo. L.J. 723 (1942). It is clear, however, that a billboard company maintaining signs on the land is a mere licensee and entitled to no compensation. Ohio Valley Advertising Corporation v. Linzell, .... Ohio St. ...., 152 N.E.2d 380 (Ohio 1957). 108 See text starting at note 152 infra.

107 Varney \& Green v. Williams, 155 Cal. 318, 100 Pac. 867 (1909). See 1 Nicrors, EMrTnent Domata \$ 1.42[8] (1958).

1081957 Hearings 116, 211, 383.

109 E.g., Pennsylvania Mut. Life Ins. Co. v. City of Philadelphia, 242 Pa. 47, 88 Atl. 904 (1913).

110 Coinment, 58 Yare L.J. 599 (1948). But cf. Adams v. Housing Authority, 60 So. $2 \mathrm{~d}$ 663 (Fla. 1952).

111 E.g., Commonwealth v. Boston Advertising Co., 188 Mass. 348, 74 N.E. 601 (1905);

Kansas City v. Liebi, 298 Mo. 569, 252 S.W. 404 (1923).

112 Redevelopment Agency v. Hayes, 122 Cal. App. 2d 777, 266 P.2d 105 (1954). See also

Rindge Co. v. County of Los Angeles, 262 U.S. 700 (1923), affirming, County of Los Angeles v. Rindge Co., 53 Cal. App. 166, 200 Pac. 27 (1921). 
uses in behalf of which the power of eminent domain may be exercised, ${ }^{113}$ and although the legislative determination is not conclusive, the courts will exercise a presunption in its favor. ${ }^{114}$ Therefore it would appear that a California court would uphold a specific statutory declaration that property may be taken to protect the view and appearance of highways, ${ }^{115}$ and furthermore such a taking would not appear to violate the due process clause of the 14th amendment. ${ }^{110}$

\section{Consideration of the zoning device}

Zoning is exercise of police power. ${ }^{117}$ By valid exercise of this power the state can, without compensation, restrict its citizens' use of their land in order to proinote the goals of public health, safety, morals, and general welfare. The principal concern of this portion of the comment is a consideration of when exercise of police power will be held valid.

\section{Zoning for aesthetics}

Restriction of outdoor advertising by zoning legislation appears to be the most effective and desirable method available to a state participating in the prograin established by section $131 .^{118}$ However, any attempts to utilize the state's zoning power to restrict billboards will surely be contested on the grounds that the only purpose of such zoning would be satisfaction of aesthetic purposes, and that fulfilment of such purposes alone does not justify use of the zoning power. ${ }^{119}$ This attack upon the constitutionality of state regulation of outdoor advertising presents a serious consideration for legislatures contemplating participation in the section 131 prograin. For, if aesthetic purposes are considered too narrow a base to support legislation, other bases for zoning must be considered. And if no valid grounds on which to predicate exercise of zoning power can be determined, condemnation and purchase, of necessity, must be employed.

Upon consideration of authorities, it appears that the majority of states allow aesthetics to be considered only as a factor supporting exercise of the

113 E.g., Cax. Code Crv. Proc. §§ 1238-1239.4.

114 Housing Authority v. Forbes, 51 Cal. App. 2d 1, 124 P.2d 194 (1942). See also Berman v. Parker 348 U.S. 26 (1954).

115 Cf. Ellis v. Ohio Turnpike Commission, 162 Ohio St. 86, 120 N.E.2d 719 (1954). (Condeunation not permitted due to statutory vagueness.)

$116 C f$., Rindge Co. v. County of Los Angeles, 262 U.S. 700 (1923), affirming, County of Los Angeles v. Rindge Co., 53 Cal. App. 166, 200 Pac. 27 (1921).

1171 Rathropf, Tae Law of Zoning and Planning 23 (3d ed. 1956).

118 The advantages of zoning may be briefly summarized: (1) more flexibility in imposing and administering control, (2) less expensive in both initial and administrative stages, (3) would require less administrative machinery, and (4) less promotive of wide-spread litigation. For the views of one state's legislative commission on the problem see Onno STATE Legislative Service Comarission, Problems Pertaining to Regulation of Outdoor AdverTISING ALONG THE INTERstate Hrghways (Information Bulletin No. 1958-2 20 (1958)).

110 Opponents of advertising control have consistently characterized regulatory measures as "aesthetic zoning." See, e.g., testimony of former Senator Scott Lucas, 1957 Hearings 204, 225.

The general statement that ordinances based solely on aesthetic reasons are invalid is accepted as the majority view in 1 Rathropf, THE LAW of ZoNING and PIANnINg 179 (3d ed. 1956). A wealth of legal literature has dissected the problem, see, e.g., Dukeminier, Zoning for Aesthetic Objectives: A Reappraisal, 20 Law \& Contemp. Prob. 218 (1955); Rodda, The Accomplishment of Aesthetic Purposes Under the Police Power, 27 So. CaL. L. REv. 149 (1954); Levin, Highway Zoning and Roadside Protection in Wisconsin, WIs. L. REv. 197 (1951); Garner, The Massachusetts Billboard Decision, 49 HARv. L. REv. 869 (1936); Profitt, Public Aesthetics and the Billboard, 16 CoRNend L.Q. 151 (1931). 
police power-and not as a sole support. However, the trend of the cases is toward recognizing aesthetics alone as a sufficient basis for exercise of police power.

The main constitutional objection to zoning measures predicated on aesthetics has been founded in the due process clause of the 14th amendment. Restriction of land use for aesthetic purposes has been considered a deprivation of property without due process of law. ${ }^{120}$ It is significant that as the judicial attitude toward invocation of due process objections to state regulatory legislation has changed, aethetics has become more acceptable as a basis for exercise of police power. ${ }^{121}$ Thus, at the same time that the United States Suprene Court had established a practical presumption against validity of state regulatory legislation, ${ }^{122}$ the state courts adopted the view that use of police power can only be based on necessity and that achievement of aesthetic values was not such a necessity. ${ }^{123}$ And as the Supreme Court softened the substantive impact of the 14th amendment by shifting the burden of proving invalidity to those claiming unconstitutionality, ${ }^{124}$ the state courts began to broaden the scope of the traditional concept of public welfare to encompass aesthetic aims, but only as long as other grounds for exercise of police power were present. ${ }^{125}$ However, this pattern has not proven consistent. For, although the Supreme Court now has adopted a strong presumption of legislative validity of state regulatory legislation, ${ }^{128}$ the state courts have not fully followed this precedent when dealing with issues under state constitution due process clauses. ${ }^{127}$ And while the Supreme Court has apparently recoguized aesthethics as a basis for police power regulation, ${ }^{128}$ only a few states have expressly based decisions approving zoning regulations on recognition of aesthetic zoning. ${ }^{120}$

120 The general rule is that if a police power regulation goes too far, it will be recognized as a taking of property for which compensation must be paid. Pennsylvania Coal Co. v. Mahon, 260 U.S. 393 (1922).

121 The historical development of judicial construction of due process is considered in Corwin, The Constitution of the UnIted States 971-980 (1953).

122 See, e.g., Loclner v. New York, 198 U.S. 45, 56 (1904).

123 "Aesthetic considerations are a matter of luxury and indulgence rather than of necessity, and it is necessity alone which justifies the exercise of the police power to take private property." Passaic v. Paterson Bill Posting Co., 72 N.J.L. 285, 62 Atl. 267, 268 (Sup. Ct. 1905).

124 See, e.g., Nebbia v. New York, 291 U.S. 502 (1934).

125 Illustrative of this view are the remarks of Clief Judge Pound in Perlmutter v. Greene, 259 N.Y. 327, 182 N.E. 5 (1932), "Beauty may not be queen, but she is not an outcast beyond the pale of protection or respect. She may at least shelter herself under the wing of safety, morality, or decency."

126 See, e.g., Olsen v. Nebraska, 313 U.S. 236 (1941).

127 California appears to reflect a view more in tune with case law prior to Nebbia $v$. New York than with Olsen v. Nebraska. See State Board of Dry Cleaners v. Thrift-D-Lux Cleaners, Inc., 40 Cal. 2d 436, 440, 254 P.2d 29, 31 (1953). For discussion of the general state handling of substantive due process cases, see Hetherington, State Economic Regulation and Substantive Dive Process of Law, 53 Nw. U.L. Rev. 13, 226 (1958); Paulsen, The Persistence of Substantive Due Process in the States, 34 MrNo. L. Rev. 91 (1950); Note, 53 Colunc. L. Rev. 827 (1953); 18 Ommo Sr. L.J. 384 (1957).

128 Berman v. Parker, 348 U.S. 26 (1954), although concerned with exercise of the power of eminent domain, a compensatory proceeding, discusses the police power's public welfare concept as inclusive of spiritual and aesthetic considerations. 348 U.S. at 33. See also Day-Brite Lighting Inc. v. State of Missouri, 342 U.S. 421, 424 (1952).

From the language and spirit of these decisions it appears that the Supreme Court would not interfere with a legislative determination to zone on solely aesthetic principles.

129 Some courts have expressly stated that valid zoning regulations may be based solely on aesthetic consideration, Merritt v. Peters, 65 So. 2d 861 (Fla. 1951); Ware v. Wichita, 113 Kan. 153, 214 Pac. 99 (1923); City of New Orleans v. Pergament, 198 La. 851, 5 So. 2 d 129 
This analysis is helpful in showing that much of the early restriction of aesthetics in zoning can be attributed to a due process doctrine that has been discarded to some extent in all jurisdictions. It should be noted along this line that most of the cases which build up a numerical majority for "no aesthetic zoning" are rather antique, ${ }^{130}$ and there is a strong possibility that anany of these courts would allow legislative choice to control in cases arising today. ${ }^{131}$

California's leading case on billboard control, Varney \& Green v. Williams, ${ }^{132}$ although generally cited as precluding the use of aesthetics as a basis for exercise of police power actually deals with a citywide prohibition of all billboards on other than property being advertised. The inclusive nature of this "radical restriction" has been poimted up in subsequent cases dealing with zoning ordinances ${ }^{133}$ and with billboard regulation in residential areas. ${ }^{134}$ The vintage of Varney $\&$ Green, as well as the possibility of distinguishing it as dealing with prohibition rather than with regulation, makes it a shaky precedent in a case arismg today under a California statute regulating billboards on Interstate Highways. However, considering that no California case has been found specifically adopting aesthetics as a valid basis for pohice power regulation and the California judicial attitude toward review of police power legislation, ${ }^{135}$ advertising control legislation in California appears open to heavy attack if aesthetics must provide the only basis for enactment. This comment will discuss three grounds for legislation which preclude the necessity of predicating billboard control on a general approval of aesthetic zoning: (1) safety,

(1941) ; General Outdoor Advertising Co. v. Dep't of Public Works, 289 Mass, 149, 193 N.E. 799 (1935) (considering the validity of a Massachusetts constitutional amendment delegating authority to regulate outdoor advertising); Preferred Tires, Inc. v. Village of Hempstead, 173 Misc. 1017, 19 N.Y.S.2d 374 (Sup. Ct. 1940) (in conflict with Mid-State Advertising Corp. v. Bond, 274 N.Y. 82, 8 N.E.2d 286 (1937)) ; Commonwealth v. Trimmer, 53 Dauph. 91, 34 Mun. 37 (Pa. Quar. Sess. 1942) (in conflict with Liggett's Petition, 291 Pa. 109, 139 Atl. 619 (1927), but see, Walnut and Quince Street Corp. v. Mills, 303 Pa. 25, 154 Atl. 29 (1931)); Connor v. City of University Park, 142 S.W.2d 706 (Tex. Civ. App. 1940) (in conflict with Spann v. City of Dallas, 111 Tex. 350 (1921)) ; State v. Wieland, 269 Wis, 262, 69 N.W.2d 217 (1955) ; Churchill and Tait v. Rafferty, 32 P.I. 580 (1915).

Many cases have found sufficient, if somewhat tenuous grounds for billboards regulation in various aspects of public safety and morals, St. Louis Poster Advertising Co. v. St. Louis, 249 U.S. 269 (1919) (danger to pedestrians from billboards collapsing in heavy winds, provides a place for conduct of immoral activities, allows collection of unsightly refuse); sec also, Cusack v. City of Chicago, 242 U.S. 526 (1917) ; St. Louis Gunning Advertising Co. v. St. Louis, 235 Mo. 99, 137 S.W. 929 (1911). For a discussion explaining these cases as an actual acceptance of aesthetics as a basis for zoning, see Dukeminier, Zoning for Aesthetic Objectives, a Reappraisal, 20 LAw \& Contemp. Prob. 218 (1955).

130 See, e.g., Curran Co. v. Denver, 47 Colo. 221, 107 Pac. 261 (1910) ; Haller Sign Works v. Physical Culture Training School, 249 Ill. 436, 94 N.E. 920 (1911).

131 An answer to the problem may be forthcoming in New York where, in connection with the construction of the New York Thruway advertising controls were imposed on a 500 foot strip adjacent to the length of the expressway. Public Authorities Law \$ 361(a) (Supp. 1958). 132155 Cal. 318, 100 Pac. 867 (1909).

133 Miller v. Board of Public Works, 195 Cal. 477, 234 Pac. 381 (1925) ; Simpson v. Los Angcles, 4 Cal. 2d 60, 47 P.2d 474 (1935).

134 People v. Norton, 108 Cal. App. 767, 288 Pac. 33 (1930). For a thorough discussion, see Rodda, The Accomplishment of Aesthetic Purposes Under the Police Power, 27 So. Cax. L. Rev. 149, 168 (1954); see also 21 Ops. CaL. AtTy. Gen. 43 (1953).

135 It might successfully be argued that cases like State Board of Dry Cleaners v. ThriftD-Lux Cleaners, Inc., 40 Cal. 2d 436, 254 P.2d 29 (1953), are limited to price and wage regulatory legislation and that the broad language of approval re zoning in Miller v. Board of Public Works, $195 \mathrm{Cal}$. 477, 234 Pac. 381 (1925), more accurately reflects judicial attitude toward legislative determination in zoning cases. 
(2) application of aesthetic zoning to commercial uses only, and (3) an analysis of the scope of the landowner's right to an easement of view from the highway.

\section{Safety}

The handiest peg on which to hang state exercise of zonimg power regarding the Interstate System is promotion of safety on the highways. An impressive argument can be constructed to show that billboards placed in critical locations-particularly on curves ${ }^{136}$ - distract the driver's attention, obscure official warning and direction signs, and present possible danger potentials im time of war. ${ }^{137}$ However, the argument can be countered by introduction of reports of some safety officials and experts stating that billboards along the highway are not only not a safety hazard, but, by virtue of their stimulative qualities, are promotive of driver safety. ${ }^{138}$ Still, there is a dispute among safety experts, ${ }^{139}$ and it appears that the courts should give almost conclusive validity to the legislative choice between two fairly debatable views. ${ }^{140}$ If, upon consideration of the problem, the legislature does find traffic safety a factor in regulating billboards, this basis for legislation should be clearly and emphatically set out by any statute adopted.

\section{Aesthetics in commercial zoning}

The grounds usually given by courts for rejecting aesthetics as a permissible basis for zoning are: (1) the inherent uncertainty of aesthetic preferences makes aesthetic choice so uncertain as to be arbitrary, and, as such, does not warrant an invasion of private rights under the gnise of the police power, ${ }^{141}$ and (2) aesthetic achievement is not clearly enough a furtherance of public welfare to allow taking of land without compensation. ${ }^{142}$ It may well be anticipated that once aesthetics is accepted as a legitimate goal of zoning, the courts will have lost the power to protect landowners from imposition of someone else's concept of attractiveness and a large loophole will have been opened for the use of those who seek to establish "restricted" neighborhoods. ${ }^{143}$ It is considered that many courts are moved by these considerations to condemn aesthetic zoning as "arbitrary." But analysis of

130 A curve location provides a most effective spot for billboard placement since the oncoming driver's line of vision is almost certain to encompass the advertising message. A study by the Minnesota Department of Elighways found, "The frequency of advertising signs per mile on curves was nearly half again as great as that found on tangent sections. MINNESOrA Rurat Truck Highway Accment, Access Potnt and Advertisng Sign Study (Revised 1952), reprinted in 1957 Hearings 240.

137 The danger of fire and splinter hazard from billboards along a defense highway was brought to the subcommittee's attention by Rear Adm. Neill Phillips, 1957 Hearings 345.

138 See Lauer and McMonagle, Do Road Signs Affect Accidents? Traffic Quarterly, July 1955. See also, testimony of J. Carl McMonagle, 1957 Hearings 309. For statistical evidence that billboards are not a safety hazard, see Planning and Traffic Division, Michigan State Highway Department, Accident Experience in Relation to Road and Roadside Features (1952).

139 For statistical evidence that billboards are a safety hazard, see Minnesota Rural Trunk Highway Accident, Access, and Advertising Sign Study (Revised 1952), reprinted in 1957 Hearings 240 .

140 See, e.g., Williamson v. Lee Optical Co., 348 U.S. 483 (1955). The question in California may be open to more doubt, see note 135 supra.

141 See Haller Sign Works v. Physical Culture Training School, 249 IIl. 436, 94 N.E. 920, 923 (1911).

142 See, e.g., General Outdoor Advertising Co. v. Indianapolis, 202 Ind. 85, 172 N.E. 309 (1930).

143 Exterior control by zoning has been accepted by a wholesale recognition of aesthetics as a basis for pohice power action in State v. Wieland, 269 Wis. 262, 69 N.W.2d 217 (1955). See also Lionshead Lake, Inc. v. Wayne Township, 10 N.J. 165, 89 A.2d 693 (1952) in which 
the advertising regulation problem may alleviate these fears, by placing billboards in their actual context of "commercial uses."

It appears clear that regulation of billboards is regulation of a commercial use. ${ }^{144}$ It is believed that although aesthetics is still considered the motivating factor, a limitation to purely commercial use zoning would relieve the courts of their well-founded fears of giving too broad a scope to zoning based on aesthetics. Also, there is indication that courts are more likely to honor a legislative determination excluding billboards when it is considered as one commercial use among many. In Criterion Services Inc. v. City of East Cleveland, ${ }^{145}$ considering the exclusion of billboards on other than the business being advertised, an Ohio Court of Appeals stated:

Outdoor Advertising is a business that is subject to classification as in all other commercial enterprises. .46

This opinion, and similar pronouncements dealing with the adoption by a city of a comprehensive zoning plan, ${ }^{147}$ lose some force in the context of state zoning of outdoor advertising along a strip of highway in unzoned, unincorporated areas. Comprehensive zoning plans are generally accorded great judicial deference, particularly in contrast to strip or spot zoning. ${ }^{148}$ However, these cases do constitute recoguition of outdoor advertising as a commercial use, and they appear to support any inunicipal attempts to accommodate the Interstate System by regulating areas adjacent to the highways, even though such land is zoned for commercial or industrial uses. They also would appear to support control of billboards located on land zoned for industrial or commercial uses by the state. ${ }^{140}$

protection of property values is accepted as a proper objective for police power legislation. For a suggestion that the general objectives of "aesthetic zoning" are in reality protection of property values and for an approval of such legislation, see Sayre, Aesthetics and Property Values: Does Zoning Promote the Public Welfare? 35 A.B.A.J. 471 (1949). For a rejection of maintenance of property values as a police power basis, see Elizabeth Lake Estates v. Waterford Township, 317 Mich. 359, 26 N.W.2d 788 (1947).

144 That the regulation of billboards inposes restraints on the owners of land is consonent with any police power regulation of commercial uses. Althougl opponents of outdoor advertising control stress the rights of the landowner, the target of such legislation is the outdoor advertising business. The landowner is involved, of course, and his rights require representation, but lis rights must be construed as capitalization on the fortuity of higliway location if they are to be seen in their proper perspective. Normally, a landowner can benefit from the proximity of public improvement and growth ; however, his riglit to capitalize on that improveinent inay well demand less deference than his right to ordinary peaceful enjoyment of the use of his lands.

In the leading case sustaining comprehensive land use plans, Euclid v. Ambler Realty Co., 272 U.S. 365 (1926), the Court sustained a zoning ordinance wlich prohibited billboards from four of the six use districts of the city. 272 U.S. at 380 (1926).

14588 N.E.2d 300 (Ohio App. 1949), appeal dismissed, 152 Ohio St. 416, 89 N.E.2d 475 (1949).

$146 I d$, at 303 .

147 See, e.g., United Advertising Corp. v. Borough of Raritan, 11 N.J. 144, 93 A.2d 362 (1952); Murphy v. Town of Westport, 131 Conn. 292, 40 A.2d 177 (1944).

148 Although no statements have been found discussing the rationale for the different lhandling of the aesthetic problem in exclusion from commercial areas cases, it is believed that the distinction can be attributed to: (1) the realization that sustaining validity in this area does not commit a court to total acceptance of aesthetics, and (2) the strong presumption of validity accorded to legislative determination in comprehensive zoning, a presumption perhaps dictated by Euclid v. Ambler Realty Co., 272 U.S. 365 (1926).

149 When land qualifies under the Cotton Amendinent, see note 22 supra, it can become 


\section{Easements of view}

The problem of billboard regulation has seldom been analyzed in terms of the landowner's legal rights in use of his land. Generally, the approaches used have assumed the right of a landowner to erect, or to allow erection of, billboards on his land and then considered the reasonableness of the proposed restriction of rights. The extent of an abutting landowner's right to an easement of reasonable view to and from the highway has been considered by some writers as too slight to support the licensing of advertising rights for uses unconnected with the land itself. ${ }^{150}$ Although California has recognized the right of an abutting landowner on a public highway to a right of reasonable view to and from the highway, ${ }^{151}$ the incidents of this riglit liave never been thoroughly considered.

It may be argued that the only easement of view recognized as compensable by California courts is the right to have signs advertising activities being conducted on the property visible from the streets. ${ }^{1 \tilde{2} 2}$ The question of compensability for obstruction of view has seldom been considered; ${ }^{153}$ however, cases involving com-

subject to the incentive payments if it meets promulgated standards. Regulation accomplished by city rather than state zoning appears applicable to $\S 131$ 's provisions.

Thus, if a state has zoned property for commercial uses, aside from the question of retroactivity discussed below, see text at note 156 supra, the state appears able to exclude billboards on the basis of these cases. Although $\S 131$ does not require such action, it is stressed again that $\S 131$ and the Regulations set up minimum standards only. If the property qualifies under the Cotton Amendment, it will be subject to the incentive payment provisions.

150 The best exposition of this view is found in Wilson, Billboards and the Right to Be Seen From the Highway, 30 Geo. L.J. 723 (1942). See also Perimutter v. Greene, 259 N.Y. 327, 182 N.E. 5 (1932); Kelbro Inc. v. Myrick, 113 Vt. 64, 30 A.2d 527 (1943). But ses Murphy v. Town of Westport, 131 Conn. 292, 40 A.2d 177, 183 (1944).

The right of view is generally termed an easement. It may be questioned whether they are true easements in the strictest sense, but they are generally recognized as at least rights in the nature of appurtenant easements, the abutting property being the dominant and the highway the servient tenement. The argument expounded by Wilson and adopted in Kelbro Inc. v. Myrick is that the servient tenement (the highway) can only be used for purposes connected with the dominant tenement (the abutting land), and that such a right of use cannot be assigned by the dominant owner to another person and so be made a right in gross or kicensed to anyone for use unconnected with the dominant tenement. This argument is refuted by Murphy v. Town of Westport, 131 Conn. 292, 40 A.2d 177, 183 (1944), which considers the right of visibility from the highway an easement appurtenant which attaches to the land and which would pass with a lease of the land.

It should be noted that a "lease" of the right to advertise is more in the nature of a hicense than a lease. See Gaether v. Donnelly, 296 Mass. 260, 5 N.E.2d 419 (1936); Walton Harvey, Ltd. v. Walker \& Homfrays, Ltd. [1931] L.R. 1 Ch. 274, 277, 280. I.e., such leases usually provide that the "lessee" shall have the exclusive right to use the land for advertising and to erect and maintain billboards on it, together with the right to go on the land for these purposes. No other interest in land is conveyed. Therefore, if the analysis of an easement of view as an easement appurtenant to a dominant tenement is accepted, the "leases" in these cases actually attempt to give only the right to be seen from the public highway and the use of land is incidental to that right. Under the view of most authorities, attempts to convey such rights apart from the dominant tenement are ineffectual. 3 TIFFANY, ReAL PROPERTY \& 761 (1939).

161 People v. Riccardi, 23 Cal. 2d 390, 144 P.2d 799 (1943); Williams v. Los Angeles Ry., 150 Cal. 592, 595, 89 Pac. 330, 332 (1907).

152 Williams v. Los Angeles Ry., 150 Cal. 592, 595, 89 Pac. 330, 332 (1907), states a restricted acknowledgment of an easement of view: "The right to have the street space kept open so that signs or goods displayed in and upon the lot may be seen by the passerby, in order that they may be attracted as customers to patronize the busmess carried on thereon." No case has been found which explicitly expands this definition.

153 The destruction of a right of view was considered compensible in People v. Ricciardi, $23 \mathrm{Cal}$. 2d 390, 144 P.2d 799 (1943), where lighway construction cut off both the right of direct access and the view of a meat market. The ease is easily distinguishable from interference with advertisements having no relation to activities conducted on the property. 
pensation for interference with a right of access aid in analysis of the problem of regulation of any private right to be seen from the highway. Damages for interference with access to the public highways are limited to consideration of the interference with the landowner's personal right of access, and not with interference with the public's access to the land. ${ }^{154}$ On analogy, it would appear that there are strong arguments that California does not recognize any compensable right of a landowner to have the public view signs on his property, other than those advertising activities conducted on the land. Therefore, it is arguable that police power regulation is the appropriate device rather than a compensatory condemnation proceeding. Exercise of police power which does not interfere with a substantial right leaves the landowner little ground on which to attack the regulation.

It should be noted that all of these cases, with one exception, ${ }^{165}$ are concerned with publically built obstructions on the highway interfering with view and not with control of the landowner's construction of billboards. However, the distinction does not appear fatal to the argument which goes to the quality of the landowner's right to use his land in a manner allowing commercial advertisements to be seen from the public highway.

\section{Retroactivity of zoning}

The Cotton Amendment to section 131 is designed to obviate problems of retroactivity. ${ }^{156}$ There are a number of states which appear bound to a rule requiring the continuation of non-conforming uses as a condition to validity of a zoning statute. ${ }^{157}$ However, it appears established in California, ${ }^{158}$ and in other jurisdictions, ${ }^{159}$ that a zonimg ordmance which provides for eventual liquidation of nonconforming uses within a prescribed period commensurate with the investment involved is valid. Therefore, California enabling legislation should provide for amortization of any non-conforming billboards which are presently located within the protected area.

\section{Consideration of the commercial purchase device}

An advertising control device that has been successfully used by some states during construction of toll roads involves an outright purchase of advertising rights. In acquiring land for the Ohio Turnpike, owners of parcels of land of which a portion was taken for right-of-way were asked to covenant as to their remaining

154 See Rose v. State of California, 19 Cal. 2d 713, 737, 123 P.2d 505, 519 (1942): "Tho damages suffered by plaintiffs is, as we have seen, the interference with their right of access. The diversion of trafic is not a proper element to be considered in computing those damages inasmuch as a landowner has no property right in the continuation or maintenance of the flow of traffic past his property."

This view was reaffirmed in People v. Ricciardi, 23 Cal. 2d 390, 401, 144 P.2d 799, 804 (1943), but that case, in effect, allowed damages for loss of public access by allowing damages for loss of view by the public of the landowner's business. See note 148 supra. For further analysis, see 32 CAIIF. L. REv. 95 (1944).

155113 Vt. 64, 30 A.2d 527 (1943).

156 See note 22 supra.

157 See 2 Ratiropf, The Law of Zoning and Planning 1 (3d ed. 1956).

158 Livingston Rock and Gravel Company v. County of Los Angeles, 43 Cal. 2d 121, 272 P.2d 4 (1954); County of San Diego v. McClurken, 37 Cal. 2d 683, 234 P.2d 972 (1951).

159 Standard Oil Co. v. Tallahassee, 183 F.2d 410 (5th Cir. 1950); State ex rel Dema Realty Co. v. McDonald, 168 La. 172, 121 So. 613 (1929). For a discussion of statutory provisions providing for amortization of existing nonconforming uses, see Levin, Highway Zoning and Roadside Protection in Wisconsin, WIs. L. Rev. 197, 214 (1951). See also Note, 35 VA. L. REv. 348 (1949). 
land against erection of any advertising devices not then in existence. ${ }^{100} \mathrm{New}$ York, while purchasing land for the New York Thruway, also obtained the right to control advertising 500 feet from the right-of-way, when possible. This systein, which is necessarily limited by the amount of land owned by one selling for right-of-way purposes, was suppleinented by pohice power regulation of all land 500 feet from the edge of the expressway. 101

The inain disadvantages of this device lie in its inability to reach all the land desired controlled and its cost. ${ }^{162}$ On the other hand, it does give the landowner some compensation for the loss of future income. It might be wise for enabling legislation to allow the state highway officials to resort to this unethod if all other techniques are inapplicable to a particular situation. ${ }^{163}$

V.

\section{THE RIGHT TO ADVERTISE}

It appears settled that the constitutional guarantees of freedom of speech and freedom of the press impose no restraint upon governinental regulation of purely commercial advertising. . $^{164}$ The question of deprivation of equal protection of the laws appears more cogent, particularly when manufacturing plants, junk yards, and coal yards may continue to blight the view after the billboards are removed. However, the usual judicial determination of this claim has been to classify outdoor advertising as a separate group of structures subject to governinental regulation on the basis of their own obnoxious qualities. ${ }^{105}$ After the necessary assunption of an evil $\mathrm{m}$ roadside bhight, the courts will in all probability find reasonable a classification regulating only billboards. ${ }^{166}$ As ably expounded during the floor fight by Senator Gore, ${ }^{167}$ restriction of outdoor advertising is, rather than a dis-

160 The covenant provided that "heirs, administrators, executors, and assigns shall not establish or maintain or permit on any of aforesaid remaining lands, any billboards, sign, notice, poster, advertising device, or other display which is visible from the travelway of ohio Turnpike project No. 1 and which is not at the date hereof in existence." 1957 Hearings 186. It should be noted that a legislative attempt to allow condemnation of advertising rights along the Ohio Turnpike was declared invalid for lack of proper standards in Ellis v. Ohio Turnpike Comm., 162 Ohio St. 86, 120 N.E.2d 719 (1954).

161 Testimony of Bertram D. Tallamy, Federal Highway Admin'r., 1957 Hearings 379, 380.

162 Generally the costs of the program in New York were rather low. Mr. Tallamy testified that buying agents pointed out to scllers that without the highway there was nothing worth selling. Where there was a refusal to sell, New York decided not to attempt to condemn the advertising rights, but rather used the police power regulation noted above. 1957 Hearings 379, 383.

${ }^{163}$ In Cahifornia it seems clear that the gas tax revenues which make up the biggest part of the state highway fund may be used to purchase or condemn advertising rights. CaL. Const. art. XXVI, § 1 (1938); CAL. STS. \& HwYs. CoDe $\$ \S 104(\mathrm{~h}), 104.3,182$. In other jurisdictions, however, the matter is not free from doubt. OHIo Legistative Service Comanission, Problems Pertanning to Regulation of Outdoor Advertistng Along the Interstate Hughivays 9 (1958).

164 Valentine v. Chrestensen, 316 U.S. 52 (1942).

105 See, e.g., the opinion of Justice Brennan when sitting on the New Jersey Supreme Court in United Advertising Corp. v. Borough of Raritan, 11 N.J. 144, 147, 93 A.2d 362, 365 (1952).

160 One who is discriminated against cannot attack a statute because it does not go further; and if what it commands of one it commands of all others in the same class, that person cannot complain of matter which the statute does not cover. West Coast Hotel Co. v. Parrish, 300 U.S. 379,400 (1937).

187104 Cong. REc. 4670 (daily ed. March 25, 1958). 
criminatory practice against a single industry, only consistent with the restrictions placed on all businesses by the decision to build a controlled access highway. In reality the advertising industry is asking for a preferred position-not for recognition of an inalienable riglit.

Granting the lack of objections on these grounds, it appears that there is a common sense distinction to be drawn among advertisers on the basis of necessity. A motel or restaurant a few miles off the higlwway has a more equitable claim to a privilege to accost the attention of a traveler than does a national brand name advertiser. Whether or not the nearby motel owner lias any constitutional right to place a sign along the Interstate Higliway System, it was the clear intent of Congress that the traveler be informed, in general terms, that services are available nearby. ${ }^{168}$ In this regard the regulations appear consistent with the statute. Still, it appears to be conceded that any right to advertise must now come from the legislature, and not from either the United States or California constitutions.

\section{VI. \\ EXCIUSION OF "HOME RULE" MUNICIPALITIES}

As previously noted the existence of jurisdictions where the municipal regulation of land use is not subject to state control accounts for certain provisions of section 131 in its final form. For instance, during the congressional debate it was stated that the state government of California under its constitution can exercise authority in the field of land use regulation only in the areas of the state which lie outside incorporated municipalities, and thus could bind itself in the agreement with the Secretary of Commerce only as to land lying outside these "home rule" communities. ${ }^{169}$ In order to accommodate this inability, section 131 provides that the agreement may allow exclusion from the application of the national standards segments of the system which traverse incorporated municipalities wherein the use of real property is subject to municipal regulation. ${ }^{170}$ This exclusion will not, however, be available to other states, notably those in the eastern part of the country where the cities and towns are subject to the laws of the state legislature as regards land use. ${ }^{171}$ To understand whether the special accommodations made for "home rule" jurisdictions were in all cases necessary, and whether a state could if it wished regulate more extensively than the federal act requires and thereby gain the incentive bonus for segments of the system lying within "home rule" municipalities, it will be necessary to analyze the law regarding "home rule" as it pertains to California.

Although the California Constitution does authorize the legislature to provide for incorporation of mumicipahties under general laws, it also provides that cities may organize under charters adopted by a board of freeliolders. ${ }^{172}$ Cities organized under this latter constitutional provision are known as freeholders cliartered cilies, ${ }^{173}$ and these municipal corporations are not subject to general laws with

\footnotetext{
168 See text at note 53 supra.
}

169104 Cong. Rec. 1335 (daily ed. Feb. 3, 1958). For this reason California's present billboard control legislation applies only to unincorporated areas. CAL. BUs. \& Pror. CODE § $5200-5325$.

17072 Stat. 904 (1958), 23 U.S.C.A. \& 171a (Supp. 1958).

1711958 Hearings 9.

172 CaL. Const. art. XI, \& 6 (1879).

173 Cal. Govt. Code $\$ 34101$. 
respect to matters which are "municipal affairs." 174 It is extremely difficult to determine what is encompassed within the protective ambit of "mumicipal affairs," especially in view of Article XI, section 11 of the California Constitution, which in effect provides that cities may enact ordinances regulating the conduct of individuals insofar as they do not conflict with the general laws. ${ }^{175}$ If the concept of "municipal affairs" is to be restricted to inatters of internal organization, such as the city's organizational structure, the payment of its employees, or its method of financing, it is clear that a zoning ordinance, the effect of which is to regulate the conduct of the citizens, would be valid only if it did not conflict with the general law. But even if the "municipal affair" doctrine is more broadly construed to include certain regulatory ordinances over matters which do not demand uniformity throughout the state or which are only of local concern, a state zoning regulation could still be deemed to supercede the local zoning provisions since the test of whether a matter is a "municipal affair" is not entirely geographical. Under certain circumstances an act relating to property withm a city may be of such general concern that its regulation may not be regarded as concerning merely a "municipal affair."176 For example, when a city street has been declared by an act of the legislature to be a secondary highway the improvement of that street is not a "mumicipal affair."177 Thus between those matters which are strictly mumicipal and others which are exclusively of state concern there is a field which has been designated as "not strictly municipal" as to which the state legislature prevails once it chooses to act. 178 Thus:

If a state statute affects a municipal affair only incidently in the accomplishnent of a proper objective of statewide concern, the state law controls rather than the charter provision in the home rule cities. The real test seems to be not whether the state or the municipality has an interest in the matter, since usually they both have, but instead whether the state's interest or that of the municipality is paramount.".179

It has been held that cities incorporated under the general laws of the state are subject to the state zoning statutes, ${ }^{180}$ but that a city incorporated under a freeholders charter exercises its zoning powers as a "municipal affair." 181 Nevertheless if the state legislature acted restrictively to zone billboards along the entire length of the Interstate System in California, including those portions traversing freeholders' chartered cities, a court would in all probability uphold this action

174 City of Grass Valley v. Walkinshaw, 34 Cal. 2d 595, 212 P.2d 894 (1949).

175 CaI. Const. art. XI, § 11 provides: "Any county, city, town, or township nay make and enforce within its himits all such local, pohce, sanitary and other regulations as are not in conflict with general laws."

The term "Inunicipal affairs" fluctuates and changes with conditions. Helmer v. Superior Court, 48 Cal. App. 140, 191 Pac. 1001 (1920). Because of this vagueness the legislative determination as to areas in which its fiat can supercede local ordinances is given a presumption of correctness by the courts. Key System Transit Co. v. City of Oakland, 124 Cal. App. 733, 13 P.2d 979 (1932).

176 In the Matter of Means, 14 Cal. 2d 254, 93 P.2d 105 (1939); Dairy Belle Farms v. Brock, 97 Cal. App. 2d 146, 217 P.2d 704 (1950).

177 Southern California Roads Co. v. McGuire, 2 Cal. $2 d$ 115, 39 P.2d 412 (1934).

178 Wilton v. Henkin, 52 Cal. App. $2 d$ 368, 126 P.2d 425 (1942).

1792 McQuilinn Municipal Corporations \$ 4.87 (3d ed. 1949); Polk v. City of Los Angeles, 26 Cal. 2d 519, 159 P.2d 931 (1945); Dept. of Water \& Power v. Inyo Chem. Co., 16 Cal. $2 d$ 744, 108 P.2d 410 (1940); Dairy Belle Farms v. Brock, 97 Cal. App. 2d 146, 217 P.2d 704 (1950).

180 Hurst v. City of Burlingame, 207 Cal. 134, 277 Pac. 308 (1929).

181 Brougher v. Board of Public Works, 205 Cal. 426, 271 Pac. 487 (1928). 
because of its merely incidental effect on "municipal affairs" and because of the paramount interest of the state in its highway system. At least a legislative determination to this effect would be entitled to great weight. ${ }^{182}$

If the legislature chose to regulate land use along the entire length of the Interstate System in California, the way would still be open for any incorporated municipahty of unusual scenic beauty to go farther in regulating billboards. If the legislature does not preempt the field, either by completely occupying it so that any act of a municipality will be inconsistant therewith, or by showing such an intention so to do, it appears that a city ordmance imposing stricter requirements than those of the state will be considered not to conflict with the general law and therefore to be valid. ${ }^{183}$

In summary, it appears at least arguable that if the state legislature desired to regulate billboards adjacent to segments of the system lying within incorporated municipalities, a statute, rather than a constitutional amendment, would be sufficient. And it appears that cities wishing to impose stricter regulation could do so in the absence of state occupation of the field by general law.

\section{VII.}

\section{CONCLUSION}

The present act is the product of a balancing of interests. It attempts to accommodate the traveler by facilitating a view of the countryside undisturbed by excesses in advertising displays, while still providing means of ascertaining specific travel information. Conversely, recognizing a legitimate interest, it allows roadside businesses to inform the traveler of their location and services. Any attempt at balancing the divergent interests represented would of necessity produce a ratlier complex result, but generally, the statute and regulations define a clear path of action. Time must determine whether the actual effect of the legislation is worthy of the effort and cost that have been and will be expended. It is conceivable that adjustments will have to be made. Also important is the decision that the attractiveness of highways can be an important consideration in legislative enactments. The impact of this policy decision will be fully appreciated only upon a later consideration of the scope and effectiveness of the state legislation which will follow the enactment of section 131. A policy decision of Congress now awaits effectuation or rejection by a policy decision of the state legislatures.

William John Martin, Jr. David E. Nelson

182 See 26 Ops. ATT'y Gen. 7 (1955) (pure water law); 25 Ops. ATT'Y Gen. 67 (1955) (community redevelopnent).

183 In the Matter of Iverson, $199 \mathrm{Cal} .582,250$ Pac. 681 (1926); In re Hoffman, $155 \mathrm{Cal}$. 114, 99 Pac. 517 (1909). 


\section{APPENDIX A}

\section{STATUTE}

Sec. 131. Areas Adjacent to the Interstate System

(a) To promote the safety, convenience, and enjoyment of public travel and the free flow of interstate commerce and to protect the public investment in the National System of Interstate and Defense Higliways, it is declared to be in the public interest to encourage and assist the States to control the use of and to improve areas adjacent to the Interstate System by controlling the erection and maintenance of outdoor advertising signs, displays, and devices adjacent to that system. It is declared to be a national policy that the erection and nuaintenance of outdoor advertising signs, displays, or devices within six hundred and sixty feet of the edge of the right-of-way and visible from the main-traveled way of all portions of the Interstate System constructed upon any part of riglit-of-way, the entire width of which is acquired subsequent to July 1, 1956, should be regulated, consistent with national standards to be prepared and promulgated by the Secretary, which shall include only the following four types of signs, and no signs advertising illegal activities:

(1) Directional or other official signs or notices that are required or authorized by law.

(2) Signs advertising the sale or lease of the property upon which they are located.

(3) Signs erected or maintained pursuant to authorization or permitted under State law, and not inconsistent with the national policy and standards of this section, advertising activities being conducted at a location within twelve miles of the point at which such signs are located.

(4) Signs erected or maintained pursuant to authorization in State law and not inconsistent with the national policy and standards of this section, and designed to give information in the specific interest of the traveling public.

(b) The Secretary of Commerce is authorized to enter into agreenents with State higlwway departments (including such supplementary agreenients as may be necessary) to carry out the national policy set forth in subsection (a) of this section with respect to the Interstate System within the State. Any such agreement shall include provisions for regulation and control of the erection and maintenance of advertising signs, displays, and other advertising devices in conformity with the standards establisled in accordance with subsection (a) of this section and may include, among other things, provisions for preservation of natural beauty, prevention of erosion, landscaping, reforestation, development of viewpoints for scenic attractions that are accessible to the public without charge, and the erection of markers, signs, or plaques, and developinent of areas in appreciation of sites of historical significance. Upon application of the State, any such agreement may, within the discretion of the Secretary of Comnerce, consistent with the national policy, provide for excluding from application of the national standards segnients of the Interstate System which traverse incorporated municipalities wherein the use of real property adjacent to the Interstate System is subject to municipal regulation or control, or which traverse other areas where the land use is clearly established by State law as industrial or commercial, and any such segment excluded from the application of such standards shall not be considered in computing the increase of the Federal share payable on account thereof.

(c) Notwithstanding the provisions of section 109 of this title, if an agreement pursuant to this section has been entered into with any State prior to July 1, 1961, the Federal share payable on account of any project on the Interstate System within that State provided for by funds authorized under the provisions of section 108(b) of the Federal-Aid Highway Act of 1956, as amended by section 8 of the Federal-Aid Highway Act of 1958, to whicl the national policy and the agreement apply, shall be increased by one-half of one per centum of the total cost thereof, not including any additional cost that may be incurred in the carrying out of the agreement. The increase in the Federal share which is payable lereunder shall be paid only from appropriations from moneys in the Treasury not otherwise appropriated, which such appropriations are hereby authorized.

(d) Whenever any portion of the Interstate System is located upon or adjacent to any public lands or reservations of the United States, the Secretary of Commerce may make such arrangements and enter into such agreements with the agency having jurisdiction over such lands or reservations as inay be necessary to carry out the national policy set forth in subsection (a) of this section, and any such agency is authorized and directed to cooperate fully with the Secretary of Commerce in this connection.

(e) Whenever a State shall acquire by purchase or condemnation the right to advertise or regulate advertising in an area adjacent to the right-of-way of a project on the Interstate 
System for the purpose of implementing this section, the cost of such acquisition shall be considered as a part of the cost of construction of such project and Federal funds may be used to pay the Federal pro rata share of such cost. Reimbursement to the State shall be made only with respect to that portion of such cost which does not exceed 5 per centum of the cost of the right-of-way for such project.

\section{APPENDIX B}

\section{REGULATIONS}

§ 20.1. Purpose. (a) In Title 23, United States Code, section 131, hereinafter called the "act," the Congress has declared that:

(1) To promote the safety, convenience, and enjoyment of public travel and the free flow of interstate commerce and to protect the public investment in the National System of Interstate and Defense Highways, hereinafter called the "Interstate System," it is in the public interest to encourage and assist the States to control the use of and to improve areas adjacent to such system by controlling the erection and maintenance of outdoor advertising signs, displays and devices adjacent to that system.

(2) It is a national policy that the erection and maintenance of outdoor advertising signs, displays, or devices within six hundred and sixty feet of the edge of the right-of-way and visible from the main-traveled way of all portions of the Interstate System constructed upon any part of right-of-way, the entire width of which is acquired subsequent to July 1, 1956, should be regulated, consistent with national standards to be prepared and promulgated by the Secretary of Commerce.

(b) The standards in this part are hereby promulgated as provided in the act.

$\S 20.2$. Definitions. The following terms when used in the standards in this part have the following meanings:

(a) "Acquired for right-of-way" ineans acquired for right-of-way for any public road by the Federal Government, a State, or a county, city or other political subdivision of a State, by donation, dedication, purchase, condeinnation, use, or otherwise. The date of acquisition shall be the date upon which title (wlsether fee title or a lesser interest) vested in the public for right-of-way purposes under applicable Federal or State law.

(b) "Centerline of the highway" means a line equidistant from the edges of the median separating the main-traveled ways of a divided Interstate higliway, or the centerline of the main-traveled way of a non-divided Interstate highway.

(c) "Controlled portion of the Interstate System" means any portion whicls

(1) Is constructed upon any part of right-of-way, the entire width of which is acquired for right-of-way subsequent to July 1, 1956 (a portion shall be deemed so constructed if, within such portion, no line norinal or perpendicular to the centerline of the highway and extending to both edges of the right-of-way will intersect any right-of-way acquired for right-of-way on or before July 1, 1956);

(2) Lies within a State, the highway department of which has entered into an agrecment with the Secretary of Commerce as provided in the act; and

(3) Is not excluded under the provisions of the act which state that upon application of a State, any such agreement may, within the discretion of the Secretary of Commerce, consistent with the national policy, provide for excluding from application of the national standards segments of the Interstate System which traverse incorporated inunicipalities wherein the use of real property adjacent to the Interstate System is subject to municipal regulation or control, or which traverse other areas where the land use is clearly established by State law as industrial or commercial.

(d) "Entrance roadway" means any public road or turning roadway, including acceleration lanes, by which traffic may enter the main-travcled way of an Interstate lighway from the general road system within a State, irrespective of whether traffic may also leave the maintraveled way by such road or turning roadway.

(e) "Erect" means to construct, build, raise, assemble, place, affix, attach, create, paint, draw, or in any other way bring into being or establish.

(f) "Exit roadway" means any public road or turning roadway, including deceleration lanes, by which traffic may leave the main-traveled way of an Interstate highway to reacli the general road system within a State, irrespective of whether traffic may also enter the main-traveled way by such road or turning roadway.

(g) "Informational site" means an arca or site established and maintained within or 
adjacent to the right-of-way of a highway on the Interstate System by or under the supervision or control of a State highway department, wherem panels for the display of advertising and informational signs may be erected and maintained.

(h) "Legible" means capable of being read without visual aid by a person of normal visual acuity.

(i) "Maintain" means to allow to exist.

(j) "Main-traveled way" means the traveled way of an Interstate highway on which through traffic is carried. In the case of a divided highway, the traveled way of each of the separated roadways for traffic in opposite directions is a main-traveled way. It does not include such facilities as frontage roads, turning roadways, or parking areas.

(k) "Protected areas" means all areas inside the boundaries of a State which are adjacent to and within six hundred and sixty feet of the edge of the right-of-way of all controlled portions of the Interstate System within that State. Where a controlled portion of the Interstate System terminates at a State boundary which is not perpendicular or normal to the centerline of the highway, "protected areas" also means all areas inside the boundary of such State which are within six hundred and sixty feet of the edge of the right-of-way of the Interstate lighway in the adjoining State.

(1) "Scenic area" means any public park or area of particular scenic beauty or historical significance designated by or pursuant to State law as a scenic area.

(m) "Sign" means any outdoor sign, display, device, figure, painting, drawing, message, placard, poster, billboard, or other thing which is designed, intended, or used to advertise or inform, any part of the advertising or informative contents of which is visible from any place on the main-traveled way of a controlled portion of the Interstate System.

(n) "State" means the District of Columbia and any State of the United States within the boundaries of which a portion of the Interstate System is located.

(o) "State law" means a State constitutional provision or statute, or an ordinance, rule, or regulation enacted or adopted by a State agency or political subdivision of a State pursuant to State constitution or statute.

(p) "Trade name" shall inelude brand name, trademark, distinctive symbol, or other similar device or thing used to identify particular products or services.

(q) "Traveled way" means the portion of a roadway for the movement of vehicles, exclusive of shoulders.

(r) "Turning roadway" means a connecting roadway for traffic turning between two intersection legs of an interchange.

(s) "Visible" means capable of being seen (whether or not legible) without visual aid by a person of normal visual acuity.

$\S 20.3$ Measurements of distance. (a) Distance from the edge of a right-of-way shall be measured horizontally along a line normal or perpendicular to the centerline of the highway.

(b) All distances under $\S 20.7$ (a) (2) and (b) shall be measured along the centerline of the highway between two vertical planes which are normal or perpendicular to and intersect the centerline of the highway, and which pass through the termini of the measured distance.

§ 20.4 Signs that may not be permitted in protected areas. Erection or maintenance of the following signs may not be permitted in protected areas:

(a) Signs advertising activities that are illegal under State or Federal laws or regulations in effect at the location of such signs or at the location of such activities.

(b) Obsolete signs.

(c) Signs that are not clean and in good repair.

(d) Signs that are not securely affixed to a substantial structure, and

(e) Signs that are not consistent with the standards in this part.

$\S 20.5$ Signs that may be permitted in protected areas. (a) Erection or maintenance of the following signs may be permitted in protected areas:

Class 1 -Official signs. Directional or other official signs or notices erected and maintained by public officers or agencies pursuant to and in accordance with direction or authorization contained in State or Federal law, for the purpose of carrying out an official duty or responsibility.

Class 2-On premise signs. Signs not prohibited by State law which are consistent with the applicable provisions of this section and $\$ 20.8$ and which advertise the sale or lease of or activities being conducted upon, the real property where the signs are located.

Not more than one such sign advertising the sale or lease of the same property may be permitted under this Class in such manner as to be visible to traffic proceeding in any one direction on any one Interstate highway.

Not more than one such sign, visible to traffic proceeding in any one direction on any one Interstate highway and advertising activities being conducted upon the real property 
where the sign is located, may be permitted under this Class more than 50 feet from the advertised activity.

Class 3-Signs within 12 miles of advertised activities. Signs not prohibited by State law which are consistent with the applicable provisions of this section and $\$ \S 20.6,20.7$ and 20.8 and which advertise activities being conducted within 12 air miles of such signs.

Class 4-Signs in the specific interest of the traveling public. Signs authorized to be erected or maintained by State law which are consistent with the applicable provisions of this section and $\S \S 20.6,20.7$ and 20.8 and which are designed to give information in the specific interest of the traveling public.

(b) A Class 2 or 3 sign, except a Class 2 sign not more than 50 feet from the advertised activity, that displays any trade name which refers to or identifies any service rendered or product sold, used or otherwise handled more than 12 air miles from such sign may not be permitted unless the name of the advertised activity which is within 12 air miles of such sign is displayed as conspicuously as such trade name.

(c) Only information about public places operated by Federal, State or local governments, natural phenomena, historic sites, areas of natural scenic beauty or naturally suited for outdoor recreation, and places for caunping, lodging, eating and vehicle service and repair is deemed to be in the specific interest of the traveling public. For the purposes of the standards in this part, a trade name is deemed to be information in the specific interest of the traveling public only if it identifies or characterizes such a place or identifies vehicle service, equipment, parts, accessories, fuels, oils or lubricants being offered for sale at such a place. Signs displaying any other trade name may not be permitted under Class 4 .

(d) Notwithstanding the provisions of paragraph (b) of this section, Class 2 or Class 3 signs which also qualify as Class 4 signs may display trade names in accordance with the provisions of paragraph (c) of this section.

$\$ 20.6$ Class 3 and 4 signs within informational sites. (a) Informational sites for the erection and maintenance of Class 3 and 4 advertising and informational signs may be established in accordance with the Regulations for the Administration of Federal-Aid for Highways. The location and frequency of such sites shall be as determined by agreements between the Secretary of Coinmerce and the State highway departments.

(b) Class 3 and 4 signs may be permitted within such informational sites in protected areas in a manner consistent with the following provisions:

(1) No sign may be permitted which is not placed upon a panel.

(2) No panel may be permitted to exceed 13 feet in height or 25 feet in length, including border and trim, but excluding supports.

(3) No sign may be permitted to exceed 12 square feet in area, and nothing on such sign may be permitted to be legible from any place on the main-traveled way or a turning roadway.

(4) Not more than one sign concerning a single activity or place may be permitted within any one informational site.

(5) Signs concerning a single activity or place may be permitted within more than one informational site, but no Class 3 sign which does not also qualify as a Class 4 sign unay be permitted within any informational site more than 12 air miles from the advertised activity.

(6) No sign may be permitted which moves or has any animated or moving parts.

(7) Ilumination of panels by other than white higlts may not be permitted, and no sign placed on any panel may be permitted to contain, include, or be illuminated by any other lights, or any flashing, intermittent, or unoving lights.

(8) No lighting may be permitted to be used in any way in connection with any panel unless it is so effectively shielded as to prevent beams or rays of hight from being directed at any portion of the main-traveled way of the Interstate System, or is of such low intensity or brilliance as not to cause glare or to impair the vision of the driver of any motor vehicle, or to otherwise interfere with any driver's operation of a motor vehicle.

$\S 20.7$ Class 3 and 4 signs outside informational sites. (a) The erection or maintenance of the following signs may be permitted within protected areas, outside informational sites:

(1) Class 3 signs which are visible only to Interstate highway traffic not served by an informational site within 12 air miles of the advertised activity;

(2) Class 4 signs which are more than 12 miles from the nearest panel within an informational site serving Interstate highway traffic to wlich such signs are visible.

(3) Signs that qualify both as Class 3 and 4 signs may be permitted in accordance with either subparagrapls (1) or (2) of this paragraph.

(b) The erection or maintenance of signs permitted under paragraph (a) of this section may not be permitted in any manner inconsistent with the following: 
(1) In protected areas in advance of an intersection of the main-traveled way of an Interstate highway and an exit roadway, such signs visible to Interstate highway traffic approaching such intersection may not be permitted to exceed the following number:
Distance from intersection:
Number of signs

$0-2$ miles

0.

2-5 miles.

6.

More than 5 miles....................................... Average of one sign per mile.

The specified distances shall be measured to the nearest point of the intersection of the traveled way of the exit roadway and the main-traveled way of the Interstate highway.

(2) Subject to the other provisions of this paragraph, not more than two such signs may be permitted within any mile distance measured from any point, and no such signs may be permitted to be less than 1,000 feet apart.

(3) Such signs may not be permitted in protected areas adjacent to any Interstate highway right-of-way upon any part of the width of which is constructed an entrance or exit roadway.

(4) Such signs visible to Interstate highway traffic which is approaching or has passed an entrance roadway may not be permitted in protected areas for 1,000 feet beyond the furthest point of the intersection between the traveled way of such entrance roadway and the maintraveled way of the Interstate bighway.

(5) No such signs may be permitted in scenic areas.

(6) Not more than one such sign advertising activities being conducted as a simgle enterprise or giving information about a single place may be permitted to be erected or maintained in such manner as to be visible to traffic noving in any one direction on any one Interstate highway.

(c) No Class 3 or 4 signs other than those permitted by this section may be permitted to be erected or maintained within protected areas, outside informational sites.

$\$ 20.8$ General provisions. No Class 3 or 4 sign may be permitted to be erected or maintained pursuant to $\S 20.7$, and no Class 2 sign may be permitted to be erected or maintained, in any manner inconsistent with the following:

(a) No sign may be permitted which attempts or appears to attempt to direct the movement of traffic or which interferes with, imitates or resenbles any official traffic sign, signal or device.

(b) No sign may be permitted which prevents the driver of a vehicle from having a clear and unobstructed view of official signs and approaching or inerging traffic.

(c) No sign may be permitted which contains, imcludes, or is illummated by any flashing, internittent or moving light or lights.

(d) No lighting may be permitted to be used in any way in connection with any sign unless it is so effectively slielded as to prevent beans or rays of light from being directed at any portion of the main-traveled way of the Interstate System, or is of such low imtensity or brilliance as not to cause glare or to impair the vision of the driver of any motor vehicle, or to otherwise interfere with any driver's operation of a motor vehicle.

(e) No sign may be permitted which moves or has any animated or moving parts.

(f) No sign may be permitted to be erected or maintained upon trees or painted or drawn upon rocks or other natural features.

(g) No sign may be permitted to exceed 20 feet in length, width or height, or 150 square feet in area, including border and trim but excluding supports, except Class 2 signs not more than 50 feet from, and advertising activities being conducted upon, the real property where the sign is located.

\$20.9 Exclusions. (a) The standards in this part slaall not apply to markers, signs and plaques in appreciation of sites of historical significance for the erection of which provisions are made in an agreement between a State and the Secretary of Commerce, as provided in the Act, unless such agreement expressly makes all or any part of the standards applicable.

(b) Whenever a State applies pursuant to the Act for the exclusion from application of the standards in this part to segments of the Interstate System which traverse incorporated municipalities wherein the use of real property adjacent to the Interstate System is subject to municipal regulation or control or which traverse other areas where the land use is clearly established by State law as industrial or commercial, and the Secretary of Commerce in the exercise of his sound discretion believes that the exclusion of such segments will be consistent with the national policy declared in the act, the agreement between him and the State higlway department will provide for such exclusion.

$\$ 20.10$ State regulations. A State may elect to prolibit signs permissable under the standards in this part without forfeiting its rights to any benefits provided for in the act. 